\title{
Potential Impacts of Induced Bank Filtration on Surface Water Quality: A Conceptual Framework for Future Research
}

\author{
Mikael Gillefalk ${ }^{1, *(D)}$, Gudrun Massmann ${ }^{2}\left(\mathbb{D}\right.$, Gunnar Nützmann ${ }^{1,3}$ and Sabine Hilt ${ }^{1, *}$ \\ 1 Leibniz-Institute of Freshwater Ecology and Inland Fisheries, Müggelseedamm 301 and 310, \\ 12587 Berlin, Germany; nuetzmann@igb-berlin.de \\ 2 Institute of Biology and Environmental Sciences, School of Mathematics and Science, Carl von Ossietzky \\ Universität Oldenburg, Uhlhornsweg 84, 26111 Oldenburg, Germany; gudrun.massmann@uni-oldenburg.de \\ 3 Geography Department, Faculty of Mathematics and Natural Sciences, Humboldt University Berlin, \\ Unter den Linden 6, 10099 Berlin, Germany \\ * Correspondence: gillefalk@igb-berlin.de (M.G.); hilt@igb-berlin.de (S.H.); \\ Tel.: +49-306-418-1741 (M.G.); +49-306-418-1677 (S.H.)
}

Received: 13 July 2018; Accepted: 8 September 2018; Published: 13 September 2018

\begin{abstract}
Studies on induced bank filtration (IBF), a cost-effective and reliable drinking water production method, usually focus on processes affecting the target drinking water quality. We aim to expand this view by assessing potential impacts of IBF on surface water quality. We suggest that IBF can directly and indirectly affect several physical, chemical and biological processes in both the sediment and open water column, eventually leading to positive or negative changes in source water quality. Direct effects of IBF comprise water level fluctuations, changes in water level and retention time, and in organic content and redox conditions in littoral sediments. Indirect effects are mainly triggered by interrupting groundwater discharge into the surface water body. The latter may result in increased seasonal temperature variations in sediment and water and reduced discharge of solutes transported by groundwater such as nutrients and carbon dioxide. These changes can have cascading effects on various water quality, e.g., by facilitating toxic phytoplankton blooms. We propose investigating these potential effects of IBF in future field and laboratory studies to allow for more detailed insights into these yet unknown effects and their magnitude in order to assure a sustainable application of this valuable technique in the future.
\end{abstract}

Keywords: drinking water; groundwater; macrophytes; lake; river; sediment; surface water-groundwater interaction

\section{Introduction}

Bank filtration (BF) is the process by which surface water infiltrates into aquifers. BF occurs when the hydraulic head in the surface water is higher than in the adjacent groundwater. This may naturally be the case, for example in lowland rivers or during high water stages, or caused by groundwater abstraction from wells next to the surface water, a process which is referred to as induced bank filtration (IBF, Figure 1). A stream, lake or river which is subject to BF is also termed a losing stream/lake/river, but water bodies may also be losing in some reaches and gaining in others [1]. It is not uncommon that groundwater abstraction in the vicinity of surface waters leads to unintentional BF, which will be included in the following discussion. 


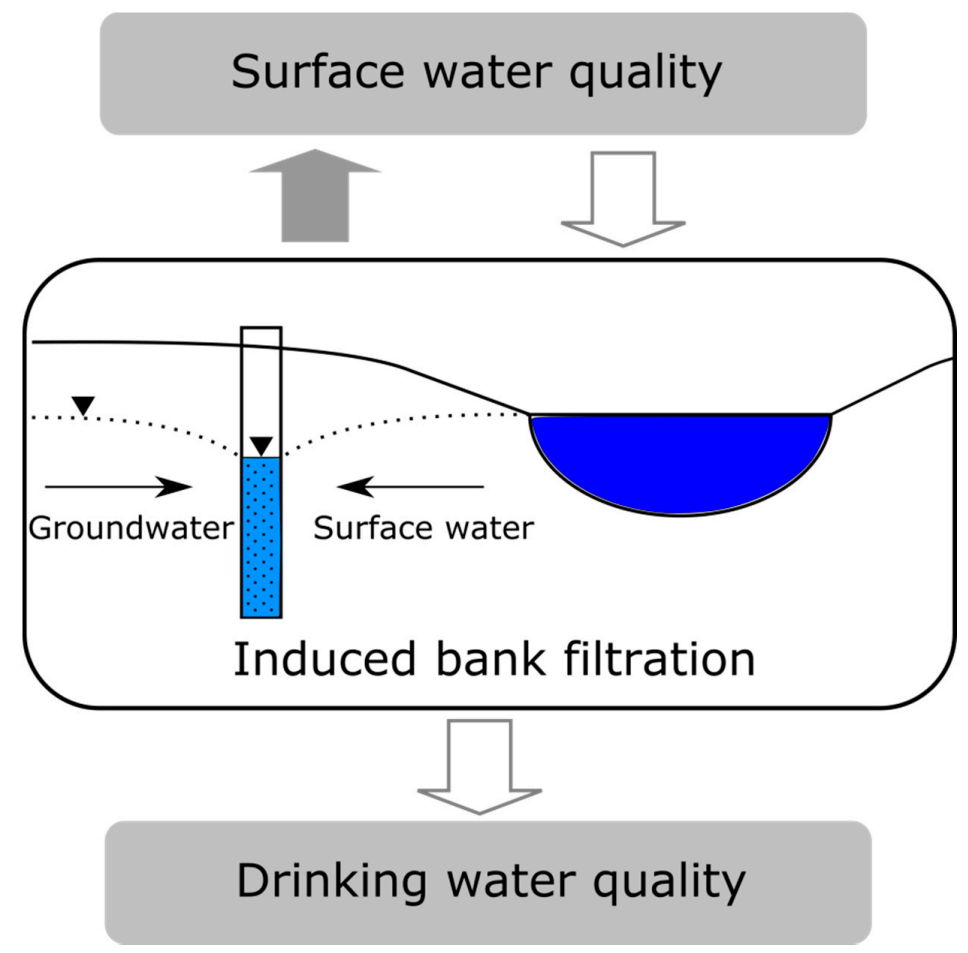

Figure 1. During induced bank filtration surface water from a source water body (dark blue) infiltrates into the sub-surface and reaches the groundwater well (light blue with dots). Traditionally, research focused on the effects of surface water and bank filtration on drinking water quality and quantity (unfilled arrows). We propose to include the neglected effects of bank filtration on surface water quality (filled arrow) into research to secure sustainable drinking water supply and sufficient ecological quality of source water bodies.

Anthropogenically induced riverbank filtration (RBF) and lake bank filtration (LBF) are alternative ways to assure a potable water supply in sufficient quality and quantity [2]. Other managed aquifer recharge methods are ponded infiltration and soil-aquifer treatment [3]. During IBF suspended solids, bacteria, viruses, parasites or adsorbable or microbially degradable water constituents are partially or fully eliminated (e.g., [4]). IBF has also been recommended as a treatment against odour problems in drinking water gained from surface water [5]. While it is generally widely acknowledged that IBF is a beneficial pre-treatment option for drinking water production, knowledge about its effects on lake and river ecosystems is very limited. Although more than half of the 524 available papers (Web of Science topic search using "*bank filtration", June 2018) have been classified into Environmental Sciences (Figure 2a), none focuses on the effects of IBF on lake or river ecosystems (one exception being Jacobson et al. [6] that deals with effects on fish habitats). Instead, research concerning IBF has almost exclusively dealt with its purification efficiency as well as infiltration capacity, maintenance considerations and other engineering issues (e.g., $[2,4,7,8]$ ). This is surprising, as the source water quality is of high importance for securing high drinking water quality and quantity (Figure 1). In the case of negative effects of IBF on surface water quality, toxic cyanobacteria blooms could occur or be worsened, which would increase the risk of toxin contamination in drinking water even after IBF $[9,10]$ and the need for chlorination [11]. Phytoplankton blooms also increase sedimentation and thus lower hydraulic conductivity and, thereby, the infiltration of surface water into the groundwater [12]. In addition, redox conditions in the sub-surface, which are also affected by surface water quality, can result in increased concentrations of dissolved iron, manganese, hydrogen-sulphide and ammonium in drinking water [4]. We argue that IBF indeed can affect surface water quality and knowledge about this interaction is needed to secure an optimal and sustainable application of this drinking water 
production technique in the future, avoiding the abandonment of IBF sites as happened in Europe in the last decades [13].

The aims of this study were to (i) assess the extent of IBF usage and the types of surface water bodies potentially affected by IBF by carrying out a literature study on case studies worldwide and to (ii) hypothesize on plausible indirect and direct effects of IBF on surface water bodies in order to (iii) develop a conceptual framework for future research assessing these effects.
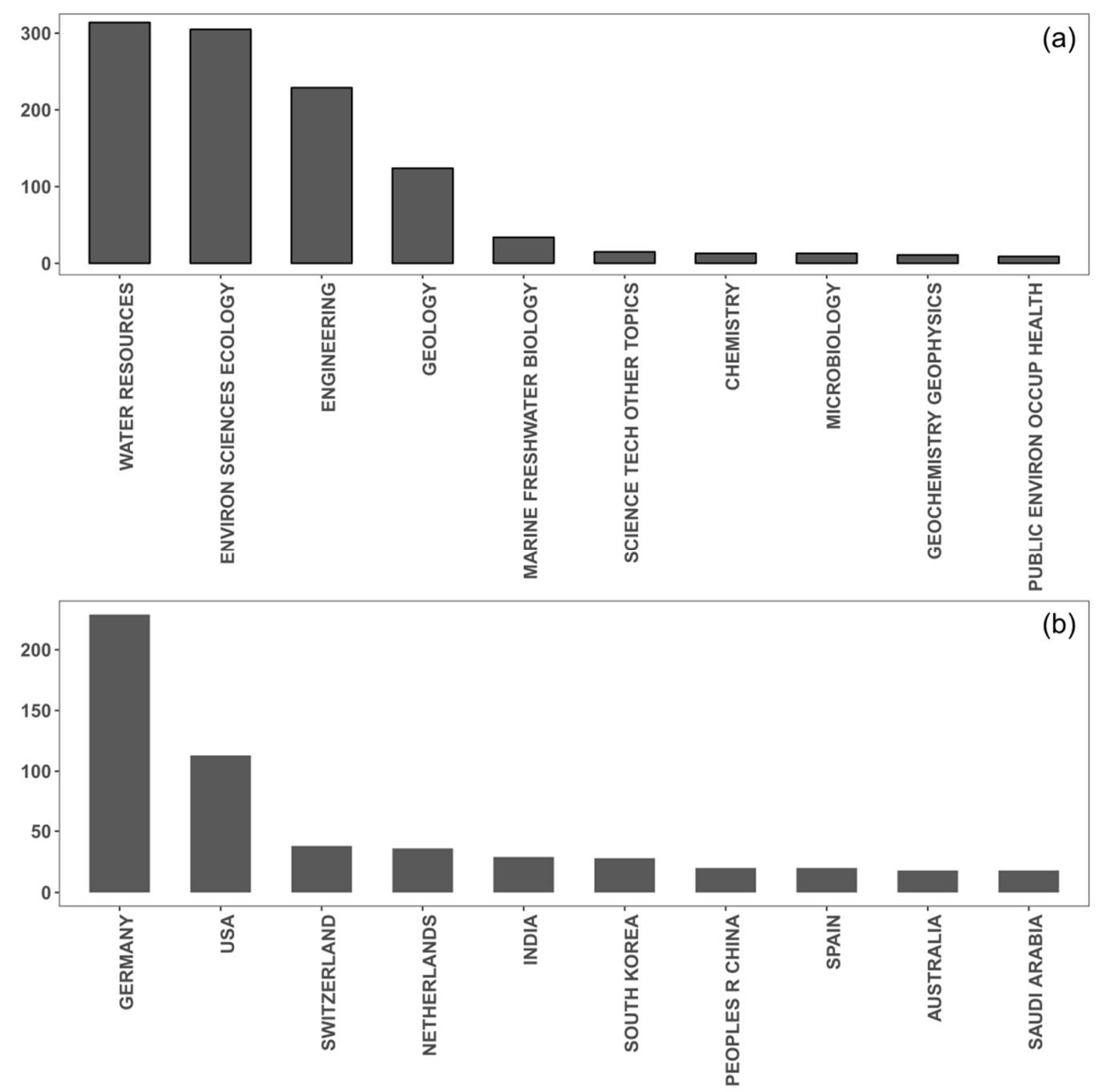

Figure 2. Top 10 studies in the categories research area (a) and countries/regions (b) of papers available on bank filtration (Web of Science topic search "*bank filtration", June 2018).

\section{Use of Induced Bank Filtration (IBF) and Source Surface Water Bodies}

\subsection{Worldwide Use of IBF and Affected Surface Waters}

IBF has been used for more than 100 years and at present is a widely applied method in many European regions [13-15] (Table 1). Drinking water derived from infiltrating river and lake water provides a significant share of potable water supplies in various European countries (Table 1). It is also used in North and South America and Asia (Table 1). IBF is not yet utilized in many developing countries, although feasibility studies have been carried out in for example Malawi and Kenya [16]. 
Table 1. Percentage of induced bank filtration (IBF) in drinking water supply of different countries/cities and source surface water bodies. The symbol " means same as above, ${ }^{*}$ indicate that info is missing, - that info is not applicable.

\begin{tabular}{|c|c|c|c|c|c|}
\hline Country & City & $\begin{array}{l}\text { Percentage of Drinking } \\
\text { Water Provided by IBF }\end{array}$ & Source Water Bodies & $\begin{array}{c}\text { River Discharge, Lake } \\
\text { Volume/Size }\end{array}$ & Reference \\
\hline Austria & * & * & River Enns & $65-206 \mathrm{~m}^{3} / \mathrm{s}$ & [17] \\
\hline " & Innsbruck & * & River Inn & $730 \mathrm{~m}^{3} / \mathrm{s}$ & [18] \\
\hline$"$ & Vienna, Linz & * & Danube & $1900 \mathrm{~m}^{3} / \mathrm{s}$ & [19] \\
\hline Bulgaria & $*$ & * & * & - & [19] \\
\hline Finland & Kuopio & * & Lake Kallavesi & 4730 million $\mathrm{m}^{3}$ & {$[20,21]$} \\
\hline " & $*$ & * & Not mentioned & * & [9] \\
\hline France & Paris region & * & Seine River & $450 \mathrm{~m}^{3} / \mathrm{s}$ & [22] \\
\hline Germany & - & 9 to 16 & - & - & {$[23,24]$} \\
\hline$"$ & Berlin & 60 & - & - & [4] \\
\hline$"$ & $"$ & - & Lake Müggelsee & 36 million $\mathrm{m}^{3}$ & [5] \\
\hline$"$ & $"$ & - & Lake Tegel & 26 million $\mathrm{m}^{3}$ & {$[5,25-32]$} \\
\hline$"$ & $"$ & - & Lake Wannsee & 15 million $\mathrm{m}^{3}$ & {$[5,12,27,33-37]$} \\
\hline$"$ & Radeburg & - & Radeburg Reservoir & $\begin{array}{c}0.35 \mathrm{~km}^{2} \\
\text { Max depth: } 3 \mathrm{~m}\end{array}$ & [38] \\
\hline$"$ & Düsseldorf & $\sim 100$ & River Rhine & $2300 \mathrm{~m}^{3} / \mathrm{s}$ & [7] \\
\hline " & Frankfurt am Main & $*$ & River Rhine & $2300 \mathrm{~m}^{3} / \mathrm{s}$ & [39] \\
\hline$"$ & " & * & Lower River Main & $193 \mathrm{~m}^{3} / \mathrm{s}$ & [39] \\
\hline$"$ & Torgau and Mockritz & * & Elbe River & $700 \mathrm{~m}^{3} / \mathrm{s}$ & [40] \\
\hline Hungary & - & 45 & - & - & [7] \\
\hline & Budapest & - & Danube & $6460 \mathrm{~m}^{3} / \mathrm{s}$ & [40] \\
\hline$"$ & $*$ & - & $\begin{array}{c}\text { Rivers Raba, Drava, Ipoly, } \\
\text { Sajo, Hernád }\end{array}$ & $\begin{array}{c}17,500 \\
21,67,27 \mathrm{~m}^{3} / \mathrm{s}\end{array}$ & [41] \\
\hline Italy & Lucca, Pisa, Livorno & $(300,000$ inhabitants) & River Serchio & $46 \mathrm{~m}^{3} / \mathrm{s}$ & [42] \\
\hline Latvia & Riga & * & $\begin{array}{l}\text { Lake Mazais } \\
\text { Baltezers } \\
\text { Lake Lielais Baltezers }\end{array}$ & $\begin{array}{l}10 \text { million } \mathrm{m}^{3} \\
18 \text { million } \mathrm{m}^{3}\end{array}$ & [43] \\
\hline The Netherlands & - & 5 & - & - & [7] \\
\hline$"$ & Remmerden & * & River Rhine & $2300 \mathrm{~m}^{3} / \mathrm{s}$ & [44] \\
\hline$"$ & Zwijndrecht & * & River Rhine & $2300 \mathrm{~m}^{3} / \mathrm{s}$ & $"$ \\
\hline$"$ & Roosteren & * & River Meuse & $276 \mathrm{~m}^{3} / \mathrm{s}$ & $"$ \\
\hline$"$ & Roermond & * & $\begin{array}{c}\text { Gravel pit lake De Lange } \\
\text { Vlieter }\end{array}$ & $\begin{array}{c}1.2 \mathrm{~km}{ }^{2} \\
\text { Max depth: } 35 \mathrm{~m}\end{array}$ & {$[45-47]$} \\
\hline$\underset{n}{\text { Norway }}$ & $\underset{\prime \prime}{\text { Hemne }}$ & * & $\begin{array}{l}\text { Lake Rovatnet } \\
\text { River Buga }\end{array}$ & $8 \mathrm{~km}^{2}$ & [48] \\
\hline Poland & Poznań & * & River Warta & $60 \mathrm{~m}^{3} / \mathrm{s}$ & [49] \\
\hline Romania & Iasi & * & Moldova River & $143 \mathrm{~m}^{3} / \mathrm{s}$ & [50] \\
\hline Slovak Republic & - & 50 & - & - & [7] \\
\hline
\end{tabular}


Table 1. Cont

\begin{tabular}{|c|c|c|c|c|c|}
\hline Country & City & $\begin{array}{l}\text { Percentage of Drinking } \\
\text { Water Provided by IBF }\end{array}$ & Source Water Bodies & $\begin{array}{c}\text { River Discharge, Lake } \\
\text { Volume/Size }\end{array}$ & Reference \\
\hline Slovenia & Maribor & - & Drava River & $500 \mathrm{~m}^{3} / \mathrm{s}$ & [40] \\
\hline Switzerland & - & $10-30$ & $\begin{array}{c}- \\
\text { River Thur }\end{array}$ & $\begin{array}{c}- \\
40-50 \mathrm{~m}^{3} / \mathrm{s}\end{array}$ & {$[13,51]$} \\
\hline UK & * & * & $\begin{array}{c}\text { Streams Wissey, Rhee and } \\
\text { Pang }\end{array}$ & $1.9,1.25,0.64 \mathrm{~m}^{3} / \mathrm{s}$ & [52] \\
\hline Canada & * & * & Lake A and B (artificial) & * & [10] \\
\hline USA & Jeffersonville & * & Ohio River & $3512 \mathrm{~m}^{3} / \mathrm{s}$ & {$[53,54]$} \\
\hline$"$ & Santa Rosa & * & Russian River & $66 \mathrm{~m}^{3} / \mathrm{s}$ & [55] \\
\hline$"$ & Cincinnati & * & Great Miami River & $109 \mathrm{~m}^{3} / \mathrm{s}$ & [56] \\
\hline$"$ & Columbus & * & Scioto/Big Walnut Creek & $6 \mathrm{~m}^{3} / \mathrm{s}$ & " \\
\hline$"$ & Galesburg & * & Mississippi River & $16,792 \mathrm{~m}^{3} / \mathrm{s}$ & $"$ \\
\hline$"$ & $\begin{array}{c}\text { Independence } \\
\text { Kansas City Parkville }\end{array}$ & $*$ & Missouri River & $2158 \mathrm{~m}^{3} / \mathrm{s}$ & " \\
\hline$"$ & Jacksonville & * & Illinois River & $659 \mathrm{~m}^{3} / \mathrm{s}$ & [56] \\
\hline$"$ & Kalama & * & Kalama River & $40 \mathrm{~m}^{3} / \mathrm{s}$ & $"$ \\
\hline$"$ & Kennewick & * & Columbia River & $7500 \mathrm{~m}^{3} / \mathrm{s}$ & $"$ \\
\hline$"$ & Lincoln & * & Platte River & $203 \mathrm{~m}^{3} / \mathrm{s}$ & $"$ \\
\hline$"$ & Mt. Carmel Terre Haute & * & Wabash River & $837 \mathrm{~m}^{3} / \mathrm{s}$ & [54] \\
\hline$"$ & Sacramento & * & Sacramento River & $660 \mathrm{~m}^{3} / \mathrm{s}$ & \\
\hline$"$ & Cape Cod & * & Ashumet Pond & 6 million $\mathrm{m}^{3}$ & [57] \\
\hline Brazil & * & * & Beberibe River & $0.3-0.4 \mathrm{~m}$ water depth & [58] \\
\hline " & * & * & Lake Lagoa do Peri & 36 million $\mathrm{m}^{3}$ & {$[59,60]$} \\
\hline China & Matan & 96 & Yellow River & $1839 \mathrm{~m}^{3} / \mathrm{s}$ & [61] \\
\hline$"$ & Baisha Town & 82.1 & Yangtze River & $31,100 \mathrm{~m}^{3} / \mathrm{s}$ & $"$ \\
\hline$"$ & Jiuwutan & 82.6 & Yellow River & $1839 \mathrm{~m}^{3} / \mathrm{s}$ & $"$ \\
\hline$"$ & Qingpu district & $70-80$ & Taipu River & $300 \mathrm{~m}^{3} / \mathrm{s}$ & $"$ \\
\hline$"$ & Xuzhou & $>80$ & Kui River & $*$ & $"$ \\
\hline$"$ & Chengdu & 80 & Yinma River & $30 \mathrm{~m}^{3} / \mathrm{s}$ & $"$ \\
\hline India & - & * & - & - & [62] \\
\hline " & Delhi & * & Yamuna River & $100-1300 \mathrm{~m}^{3} / \mathrm{s}$ & [63] \\
\hline$"$ & Satpuli & * & East Nayar River & - & \\
\hline " & Srinagar & * & River Alaknanda & $507 \mathrm{~m}^{3} / \mathrm{s}$ & [64] \\
\hline$"$ & Haridwar & * & River Ganga & $1455 \mathrm{~m}^{3} / \mathrm{s}$ & [65] \\
\hline$"$ & Nainital & * & Lake Nainital & 6 million $\mathrm{m}^{3}$ & [66] \\
\hline Malaysia & Kuala Kangsar & * & Sungai Perak (river) & $57 \mathrm{~m}^{3} / \mathrm{s}$ & [67] \\
\hline South Korea & * & * & Nakdong River & $37-3462 \mathrm{~m}^{3} / \mathrm{s}$ & [68] \\
\hline Thailand & Chiang Mai & * & Ping River & $287 \mathrm{~m}^{3} / \mathrm{s}$ & [69] \\
\hline Egypt & - & 0.1 (increasing) & Upper Nile & $1548 \mathrm{~m}^{3} / \mathrm{s}$ & [70] \\
\hline "1 & Sidfa & * & Nile & $2830 \mathrm{~m}^{3} / \mathrm{s}$ & [71] \\
\hline$"$ & Aswan & * & & & [72] \\
\hline
\end{tabular}


Most of the published studies on IBF stem from Germany $(44 \%)$ and the USA (22\%, Figure $2 \mathrm{~b}$ ). Germany is the country in Europe with the most IBF sites 46 [13], but studies have been produced in a total of 57 countries (Web of Science topic search using "*bank filtration", June 2018). According to the Federal Statistical Office of Germany [23], 8.6\% of drinking water in Germany originates from IBF, while another $8.8 \%$ is defined as "recharged groundwater", consisting mainly of intentionally recharged surface water. Schmidt et al. [24] state that around $16 \%$ of the drinking water in Germany is produced from IBF and other infiltration sites, with more than 300 waterworks using IBF and roughly 50 using artificial groundwater recharge. From a total of 56 studies on IBF mentioning its source water bodies, there were 15 lakes or ponds and 48 different rivers being used for IBF (Table 1). When IBF is conducted along large rivers, such as the Rhine or the Danube, where discharge rates are of a magnitude of $10^{3} \mathrm{~m}^{3} / \mathrm{s}$ and thus much higher than groundwater influx and abstraction rates (e.g., IBF in Düsseldorf at River Rhine: $0.06 \%$ of discharge [73]), the effect of IBF on source water quality is, if not completely negligible, at least very small. In contrast, water quality of lowland rivers, ponds and lakes can potentially be affected by IBF due to their lower discharge (e.g., Lake Müggelsee: up to $50 \%$ of discharge, see below).

\subsection{Example of IBF Application in Berlin (Germany)}

IBF was first applied in Germany's capital, Berlin, more than 100 years ago. For the past 70 years, bank filtration has produced approximately $60 \%$ of the city's drinking water $[4,74]$. Water abstraction in Berlin occurs in around 650 wells [75] and is part of a semi-closed water cycle, where effluents from waste water treatment plants reach surface water bodies subject to water extraction via IBF for water provisioning (Figure 3). In total, 9 lakes and many reaches of the lowland rivers Spree, Dahme and Havel are affected by IBF (Figure 3).

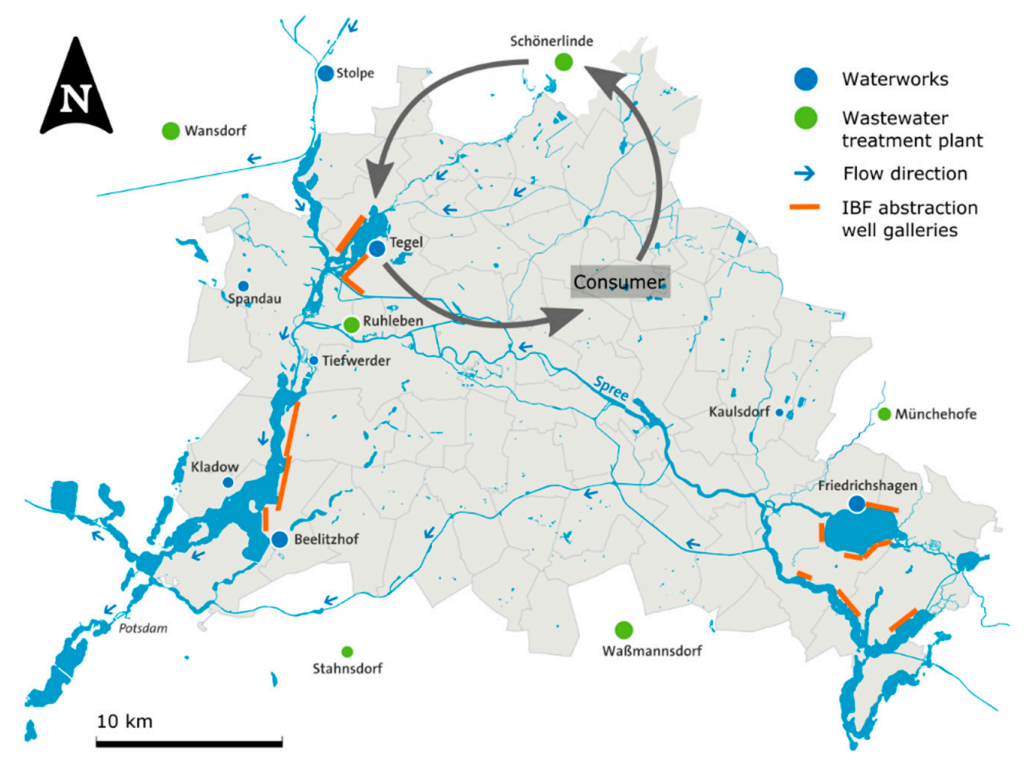

Figure 3. Bank filtration as part of a semi-closed water cycle. The water bodies of Berlin with waterworks, wastewater treatment plants and IBF abstraction well galleries, after Berlin Water Utilities [76] and Jekel et al. [77]. Most of the Berlin surface waters are part of a semi-closed water cycle where water is being abstracted via bank filtration where treated wastewater is released.

In Lake Müggelsee (Figure 4a), mean depth $=4.9 \mathrm{~m}$, surface area $=7.3 \mathrm{~km}^{2}$ [78], groundwater historically discharged into the lake under natural conditions, especially at the northern shore [79] (Figure 4c). However, groundwater withdrawal from well galleries near the shore started in 1905 [78]. Currently, IBF is performed via 170 wells located along the northern, western and southern shore (Figure 4a). Pumping rates are around $40-45$ million $\mathrm{m}^{3}$ per year (Figure $4 \mathrm{~b}$ ) distributed among the wells surrounding the lake [80], resulting in a lowering of the groundwater level of by up to $5 \mathrm{~m}$ 
(Figure 4a,c), which is in accordance with groundwater models for the catchment area around Lake Müggelsee [79]. Zippel and Hannappel [74] calculated that 78.4\% of the water reaching the abstraction wells was bank filtrate and a substantial part of the lake water was lost via IBF, with the total volume lost each year being almost equal to the volume of the lake (36 million $\mathrm{m}^{3}$ [78]).
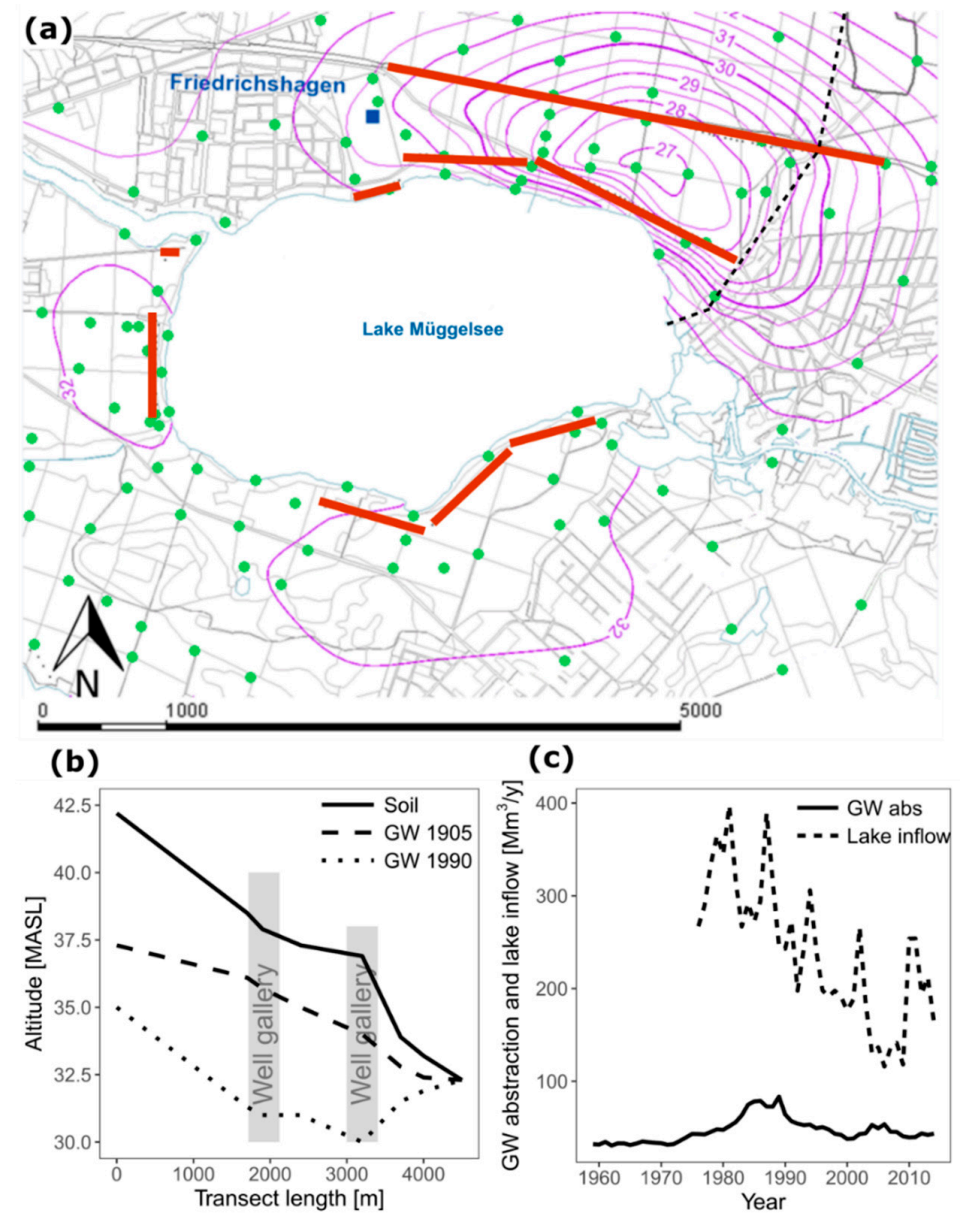

Figure 4. Bank filtration at Lake Müggelsee, Berlin, Germany. (a) Groundwater isolines for 2015 (purple lines with numbers indicate groundwater levels in meter above sea-level), well galleries with a total of 170 groundwater abstraction wells (red lines), groundwater monitoring wells (green points) around Lake Müggelsee (Germany). The transect of groundwater levels shown in panel $b$ is indicated with dashed black line. Background map including wells provided by the Senate of Berlin, Department of urban development and housing via the FISBroker (Fachübergreifendes InformationsSystem) online mapping tool [81]. (b) Groundwater (GW) levels (MASL = meter above sea lelvel) from 1905 (before groundwater abstraction started) and 1990 (with active pumping) along a north-south transect north of Lake Müggelsee (after Frey et al. [82]). The transect is indicated in panel a. (c) Yearly abstraction rates (solid line) of all wells surrounding Lake Müggelsee (galleries A-F) 1959-2014 [80] and surface water discharge (dotted line) into Lake Müggelsee 1976-2014 [83,84].

During the period 2014-2017 an estimated $1.1 \mathrm{~m}^{3} / \mathrm{s}$ water was extracted from Lake Müggelsee on average [80], which corresponded to about $28 \%$ of the amount of water flowing into Lake Müggelsee via the river Spree within the same period [83,84] (Figure 4b). During periods of low inflow this proportion increased and reached at least $50 \%$ on around a fifth of the days, mostly in summer. The amount of groundwater that would reach Lake Müggelsee if no abstraction took place [79] can be estimated by using the pumping rate of the northernmost well galleries (A and $B$ ) north of the lake. In the period 2014-2017 the rate was on average $0.4 \mathrm{~m}^{3} / \mathrm{s}$ [80] and in the same time period the surface water inflow to Lake Müggelsee was $3.9 \mathrm{~m}^{3} / \mathrm{s}$ [83], which means that the retention time is $10 \%$ 
longer with IBF (107 days compared to 97). Longer retention times also mean a lower flushing rate of nutrients. Comparison of the nutrient retention with and without IBF using the method described by Vollenweider [85] shows that the total phosphorus $(\mathrm{P})$ concentration was $9 \%$ higher with IBF (ingoing values: $\mathrm{P}$ load $=2000 \mathrm{mg} / \mathrm{m}^{2} /$ year [86], discharge $=3.9 \mathrm{~m}^{3} / \mathrm{s}$ (with IBF) or 4.3 (without IBF) $\mathrm{m}^{3} / \mathrm{s}$ ) compared to if groundwater would reach the lake from the north. These numbers give a first impression of potential impacts by IBF but in order to show detailed effects on lake ecology, field measurements and/or modelling are needed.

\section{IBF Effects on Surface Water Quality}

Induced bank filtration can potentially affect surface water bodies via two major pathways: (1) directly by induced infiltration of surface water into river and lake sediments; and (2) indirectly by preventing groundwater exfiltration into surface waters. This chapter examines potential IBF effects on physical and chemical parameters affecting biological parameters and processes and eventually surface water quality. In the following paragraphs we first describe the general effects of each respective parameter on water quality and then how IBF potentially changes the parameter.

\subsection{Discharge and Retention Time}

The flow regime is regarded as key driver of river and floodplain wetland ecosystems [87]. In rivers, low-flow conditions and thus degradation of rivers due to groundwater abstraction and thus unintentional BF has been detected, e.g., in Great Britain [88,89]. Similar problems are expected to be caused by IBF. Lower discharge and water levels in rivers severely change the habitat conditions for macrophytes (e.g., [90]), macroinvertebrates (e.g., [91]) and fish (e.g., [6]). Although the impacts of changes in discharge are manifest across broad taxonomic groups, ecologists still struggle to predict and quantify biotic responses to altered flow regimes [87]. We expect effects on biodiversity, macrophyte abundance, and potentially even the occurrence of harmful cyanobacteria blooms, but the effects depend on the initial conditions (Table 2). Jacobson et al. [6] used a model to show how changing pumping schedules of groundwater extraction well fields could improve the living conditions for fish in a stream by varying water extraction rates and avoiding discharge rates below certain critical thresholds for more than a limited time, thereby ensuring sufficient usable area and discharge.

Higher retention times in lakes have been reported to affect the interaction between phytoplankton and macrophytes. In shallow lakes, this interaction results in the occurrence of alternative stable states with either macrophyte dominance and clear water or phytoplankton-dominated, turbid conditions (see Section 4.2). At higher retention times, this phenomenon is more likely to occur, which has consequences for the management of the waters [92]. Higher retention times also affect nutrient retention, as shown in the Lake Müggelsee case study, where a 10\% increase in retention time was estimated to cause a 9\% higher total P-concentration (see Section 2.2). In summer, when natural flow is low and water demand is higher, the retention time in lakes naturally increases, hence the effect of IBF is more pronounced then. 
Table 2. Potential effects of induced bank filtration on physical $(\mathrm{WT}=$ water temperature, $\mathrm{RT}=$ retention time, $\mathrm{WL}=$ water level) and chemical (DIC = dissolved inorganic carbon, $\mathrm{DOC}=$ dissolved organic carbon, pollutants such as pharmaceutical remnants and microplastics) parameters in surface waters (mechanisms: D: directly, I: indirectly due to the interruption of groundwater discharge) and examples for subsequent effects on biological parameters. The symbol "+" means that the effect will enhance the affected biological parameter, "-" that the effect will decrease the parameter, and "?" that the outcome is uncertain. The predicted effects within the parameter categories are roughly ordered according to our estimate of likelihood of occurring.

\begin{tabular}{|c|c|c|c|c|c|c|}
\hline Parameter & Predicted Effect & Mechanism & References & $\begin{array}{l}\text { Affected Biological } \\
\text { Parameter }\end{array}$ & Effect & $\begin{array}{c}\text { References } \\
\text { (Example) }\end{array}$ \\
\hline \multirow{21}{*}{ Physical } & \multirow{3}{*}{ Higher summer WT } & \multirow{3}{*}{ I } & \multirow{3}{*}{ [93] } & Biodiversity & \pm & [94] \\
\hline & & & & Macrophyte dominance & - & [95] \\
\hline & & & & Harmful blooms & + & [95] \\
\hline & \multirow{3}{*}{ Lower winter WT } & \multirow{3}{*}{ I } & \multirow{3}{*}{ [96] } & Biodiversity & $?$ & \multirow[t]{3}{*}{ [97] } \\
\hline & & & & Macrophyte dominance & - & \\
\hline & & & & Harmful blooms & $?$ & \\
\hline & \multirow{3}{*}{ Higher RT } & \multirow{3}{*}{$\mathrm{D}, \mathrm{I}$} & & Biodiversity & \pm & [98] \\
\hline & & & & Macrophyte presence & \pm & [92] \\
\hline & & & & Harmful blooms & \pm & [99] \\
\hline & \multirow{3}{*}{ Lower flow } & \multirow{3}{*}{ D, I } & \multirow{3}{*}{ [89] } & Biodiversity & \pm & [87] \\
\hline & & & & Macrophyte presence & \pm & [100] \\
\hline & & & & Harmful blooms & + & [101] \\
\hline & \multirow{3}{*}{ Sediment clogging } & \multirow{3}{*}{$\mathrm{D}$} & \multirow{3}{*}{ [26] } & Biodiversity & $?$ & \multirow[t]{3}{*}{ [102] } \\
\hline & & & & Macrophyte dominance & \pm & \\
\hline & & & & Harmful blooms & $?$ & \\
\hline & \multirow{3}{*}{ Lower WL } & \multirow{3}{*}{$\mathrm{D}, \mathrm{I}$} & \multirow{3}{*}{ [103] } & Biodiversity & $-(?)$ & \multirow{3}{*}{ [99] } \\
\hline & & & & Macrophyte presence & - & \\
\hline & & & & Harmful blooms & + & \\
\hline & \multirow{3}{*}{$\begin{array}{l}\text { Stronger WL } \\
\text { fluctuations }\end{array}$} & \multirow{3}{*}{$\mathrm{D}, \mathrm{I}$} & \multirow{3}{*}{ [103] } & Biodiversity & \pm & \multirow{3}{*}{$\begin{array}{l}{[104]} \\
{[105]}\end{array}$} \\
\hline & & & & Macrophyte presence & - & \\
\hline & & & & Harmful blooms & $?$ & \\
\hline \multirow{15}{*}{ Chemical } & \multirow{3}{*}{ Lower DIC } & & & Biodiversity & \pm & [98] \\
\hline & & I & [106] & Macrophyte dominance & - & [107] \\
\hline & & & & Harmful blooms & \pm & [108] \\
\hline & & & & Biodiversity & + & [109] \\
\hline & $\begin{array}{l}\text { Lower external } \\
\text { nutrient load }\end{array}$ & I & & Macrophyte dominance & + & [110] \\
\hline & & & & Harmful blooms & - & [108] \\
\hline & & & & Biodiversity & $+(?)$ & [111] \\
\hline & Lower DOC & I & [106] & Macrophyte dominance & $+(?)$ & [112] \\
\hline & & & & Harmful blooms & $+1-$ & {$[113] /[114]$} \\
\hline & & & & Biodiversity & + & [115] \\
\hline & $\begin{array}{l}\text { Lower poinutant } \\
\text { load }\end{array}$ & I & & Macrophyte dominance & $+(?)$ & \\
\hline & & & & Harmful blooms & $?$ & \\
\hline & & & & Biodiversity & - & [115] \\
\hline & $\begin{array}{l}\text { Higner pollutant } \\
\text { load in the littoral }\end{array}$ & I & & Macrophyte dominance & $-(?)$ & \\
\hline & & & & Harmful blooms & ? & \\
\hline
\end{tabular}

\subsection{Water Level Fluctuation}

Fluctuation of the water level can be a key factor affecting the functioning of lakes (e.g., $[109,116])$ and rivers (e.g., [104]).

Decreasing water levels may cause former submerged habitats to be exposed to air, resulting in a loss of habitats for littoral plants and animals [117]. Groundwater abstraction was believed to have affected 151 wetland sites of special scientific interest (SSSIs) throughout England and Wales, with 100 additional wetlands perceived to be at future risk [89]. In lakes, water depth and resuspension of sediments due to wind effects are strongly linked [118]. Depending on the lake morphometry, low water levels would enable the wind at a sufficient speed to affect parts of the lake bottom that otherwise would not be affected, especially in shallow lakes. Also, a shallower depth would increase the area of the lake that may be bottom frozen, to which some macrophyte species are sensitive [97]. In 
Estonia, ground water abstraction starting in 1972 caused lower water levels in three lakes, reaching a decline of up to 3-4 $\mathrm{m}$ in the 1980s. This led to the switch from a clear-water to a turbid state in two of the lakes, with subsequent loss of submerged macrophytes. In the 1990s the pumping decreased and the water levels were partially recovered, but the macrophytes did not return [103]. In winter, evergreen macrophytes may become partly fixed in the ice when it forms.

Water-level fluctuations may be an important trigger for the promotion of cyanobacterial blooms ([99] and references therein). In shallow lakes, water level fluctuations may trigger shifts from the clear-water, macrophyte-dominated state to the turbid, cyanobacteria-dominated state (see Section 4.2). In deep reservoirs changing water levels may result in a compressed vertical niche for macrophytes [105] and consequently reduce their inhibiting effects on cyanobacteria [119].

Induced bank filtration has the potential to decrease the water levels of inland waters or increase water level fluctuations in the case of fluctuating pumping regimes (Table 2). These effects are caused directly and indirectly by surface water infiltrating into the sub-surface and by the prevention of groundwater discharge, respectively (Table 2). Various effects of such changes on our target biological parameters have been reported (Table 2). The effects of IBF on surface water quality via effects on water level and its fluctuation strongly depend on a range of additional parameters such as lake morphology, the presence of other regulation measures for water level and background nutrient concentrations. Often, BF-induced water level changes will not be a major factor affecting surface water quality as many lakes and rivers in urban or developed regions are flow- and level regulated.

\subsection{Sediment Characteristics}

The purification efficiency and infiltration capacity of IBF rely strongly on the characteristics of the sediments where the infiltration of surface water takes place. Therefore, several studies have investigated clogging and redox processes at IBF sites [12,25,26,120]. Most of the purification happens within the first few meters of water transport through the sediment and the following soil layers, although the first few centimetres are already very important for the IBF performance ([14] and references therein) [27,33]. At Lake Tegel (Berlin, Germany), the waterworks pump 45 million $\mathrm{m}^{3}$ /year from six wellfields around the lake, and two on the islands in the lake. Pumping from these wells affects hydraulic heads within an area of $50 \mathrm{~km}^{2}$ [121]. Biological clogging with particulate organic matter (POM) reached down to at least $10 \mathrm{~cm}$ in the sediments. However, complete clogging did not occur in the sediments, probably due to microbial carbon turnover [25], feeding by detritivorous meiofauna [122] and opening of pores by wave action [26]. The result is a highly active biological zone with algae, bacteria, produced extracellular polymeric substances and meiofauna that still allows for IBF [26]. At low levels of labile organic matter content in the sediments, this process may facilitate macrophyte growth, but with increasing organic matter content the growth rate instead decreases [102]. Low redox potential also negatively impacts certain macrophytes' propagule emergence [123]. In addition, phosphorus ([124] and references therein) and toxic substances [125] can be released and lead to macrophyte decline and cyanobacteria blooms (Table 2, see also Sections 4.1-4.3). In surface waters with high sulphate $\left(\mathrm{SO}_{4}{ }^{2-}\right)$ concentrations, e.g., due to lignite mining in the catchment [126], hydrogen sulphide $\left(\mathrm{H}_{2} \mathrm{~S}\right)$ might form, which has been shown to be harmful to macrophytes [127].

The infiltration of oxic surface water can also oxidise upper parts of the sediments, especially during periods of high photosynthetic activity of primary producers in the surface water, but studies comparing sediment surface oxygen concentrations with and without IBF are mostly lacking. One exception being Bayarsaikhan et al. [128] who reproduced IBF processes in a laboratory setting and found that degradation of particulate organic carbon (POC) in the form of small pieces of leaf litter consumed almost all oxygen in the sediments. 


\subsection{Water Temperature}

Water temperature is increasingly recognized as an important and highly sensitive driver of water quality [129]. As most biological processes are temperature-dependent, a water temperature regime change can have several consequences for aquatic organisms and their interactions. Temperature directly influences the distribution (e.g., [130-132]), predator-prey interactions (e.g., [133]), survival (e.g., [134], growth rates (e.g., [135-138]), timing of life history events (e.g., [139,140]) and metabolism (e.g., [141,142]) of aquatic organisms in river and lake systems. Immediate effects of higher water temperatures in spring and summer are higher growth rates of primary producers and subsequent changes in their interactions which are crucial for maintaining clear-water conditions (see Section 4.3), as studied in several mesocosm experiments (e.g., [143-146]). Higher summer water temperatures also promote potentially toxic cyanobacteria blooms, which severely deteriorate water quality (e.g., [147-149]). In addition, mineralization of organic matter is fuelled by increasing temperatures and may result in a release of organic-bound $P$ to the sediment pore water [150]. For shallow temperate lakes, Mooij et al. [95] predicted an increased probability of a shift from a clear to a turbid state due to climate change. Their model also predicts higher summer chlorophyll-a concentrations, a stronger dominance of cyanobacteria during summer and reduced zooplankton abundance.

Groundwater usually has a rather stable temperature similar to mean annual air temperatures; for example, groundwater temperatures in Germany vary between $10-12{ }^{\circ} \mathrm{C}$ [151]. This fact is often taken advantage of when identifying groundwater discharge zones in surface water by aerial or hand-held thermal infrared (IR) imagery (e.g., [152]). Groundwater infiltrating into surface waters thus has a cooling effect in summer, while it may warm surface waters in winter, as described in Sebok et al. [153]. Another example showed a $3{ }^{\circ} \mathrm{C}$ lower water temperature in summer in the part of a lake where groundwater discharged compared to other parts of the same lake [93]. In rivers, groundwater discharge can help keep certain parts free from ice in winter and provide cooling in summer, thereby providing a refuge for fish [135]. Consequently, a change from gaining to losing conditions in a river or lake will result in an increased amplitude of the seasonal temperature variations in surface waters. This may result in a loss of the temperature buffering function of discharging groundwater against surface water freezing in winter and against heating during summer. A lowering of temperatures in winter could lead to increased risk of bottom frozen lakes (see Section 3.2). The effect size on changing temperature buffering depends on the ratio between river discharge and lake volume on the one hand and the abstraction rate on the other. A large river would be less affected than a small river, while for lakes, the size is of less importance since the change would primarily take place in the littoral zone.

A full assessment goes beyond the scope of this study, but effects of IBF-induced temperature increases in summer can be similar to those of climate change-induced warming, especially for benthic organisms in the littoral zone which is highly likely to be warmer with IBF in summer due to the prevention of cold groundwater inflow. Overviews of climate warming effects on lake and river ecosystems are provided by Adrian et al. [94] and Whitehead et al. [154], respectively.

\subsection{Nutrient Availability}

Although groundwater often has lower nutrient concentrations than surface water, groundwater discharge has been reported as a potential source of additional nutrient (mainly nitrogen and P) loading from anthropogenic sources such as agricultural fertilizers, both in lakes $[107,155,156]$ and rivers [157]. These groundwater-borne nutrients may facilitate the growth of all primary producers and affect their interactions ([107] and references therein), with mostly negative effects on biodiversity and macrophyte abundance (see Sections 4.1-4.3, Table 2). In oligotrophic systems, submerged macrophytes may either be supported by nutrients from groundwater exfiltration or decline due to competition from periphyton $[107,158]$. The process of increased nutrient loading to surface waters (eutrophication) often leads to the disappearance of submerged macrophytes [159] and shifts to the turbid state, especially in shallow lakes [160,161] (see Section 4.2), but also lowland rivers [92,162]. 
Lake Arendsee (Germany) receives more than $50 \%$ of its external P loads from groundwater, which significantly adds to its eutrophication [156]. Furthermore, groundwater discharge not only transports nutrients from the catchment into surface waters, but also contributes to a transport of nutrients from sediment pore waters into surface water [158]. Interrupting these loads by installing groundwater wells to induce BF could prevent these nutrients from reaching the surface water and thus contribute to a significant increase in water quality, both through a reduction of the limiting nutrient or by changing the nutrient stoichiometry. In contrast, nutrient-poor groundwater would contribute to a dilution of nutrient-rich water entering lakes or rivers from other sources. Mitigating this dilution effect by inducing BF would not affect the nutrient loading but reduce the actual nutrient concentrations. Furthermore, groundwater is often rich in Fe and Mn which can increase the P-binding capacity. Also, as noted in Sections 2.2 and 3.1, groundwater exfiltration lowers the retention time in lakes and helps flush the lake of nutrients.

\subsection{Pollutants}

In general, degradation of contaminants is less efficient in groundwater than in surface water sediment [163]. Antibiotics reaching the groundwater have been shown to change microbial community structure, enhance antibiotic resistance and thereby change ecological functions within the aquifer [164]. Remnants of personal care products and microplastics have been shown to accumulate in sediments $[165,166]$ and to persist there more than in water $[167,168]$. This accumulation potentially increases by IBF with expected positive effects for pelagic, but negative effects for benthic organisms.

In case the source surface water contains pollutants, more of them could reach the littoral zone and its sediments through IBF, which might facilitate their degradation due to the higher bioactivity, but also change the community structure and abundance of sediment bacteria (e.g., [169]).

In cases where pollutants are transported into surface water by groundwater discharge (e.g., [170]), IBF could interrupt the groundwater flow and thereby stop pollutants from reaching surface water bodies. In cases where concentrations of pollutants are high, groundwater wells would most likely not be installed, but at low concentrations they might be. In such cases, the lake would benefit from pollutant mitigation by IBF.

\subsection{Dissolved Inorganic Carbon (DIC) Availability}

All aquatic plants can use $\mathrm{CO}_{2}$ as a carbon source [171,172], and since the $\mathrm{CO}_{2}$ concentration needed to half-saturate the photosynthesis of aquatic plants in general is approximately 6-13 times atmospheric levels [173] additional sources are needed. Most lakes of the world (87\%) are $\mathrm{CO}_{2}$ supersaturated [174] and $\mathrm{CO}_{2}$ originates from mineralization of organic material in sediments and in the water column, from diffusion from the air but also from surface and groundwater inflow ([175] and references therein). In some cases, groundwater is the sole source of the dissolved inorganic carbon (DIC) influx to lakes ([107] and references therein) and the majority of boreal lakes are $\mathrm{CO}_{2}$-sustained by groundwater [175]. In tropical and temperate lakes, $\mathrm{CO}_{2}$ supersaturation is dependent on groundwater $\mathrm{CO}_{2}$ coming from weathering of minerals [176]. Groundwater in general often contains at least 35 times higher concentrations of $\mathrm{CO}_{2}$ than lakes $[177,178]$, up to 400 times higher in some cases $[179,180]$.

Many macrophyte species have the ability to use $\mathrm{HCO}_{3}{ }^{-}$as a carbon source in addition to free $\mathrm{CO}_{2}$ [181,182]. The use of $\mathrm{HCO}_{3}{ }^{-}$entails higher energetic costs [183]; therefore, macrophytes able to use $\mathrm{HCO}_{3}{ }^{-}$still grow faster in a $\mathrm{CO}_{2}$-rich environment [184]. Other species are fully dependent on $\mathrm{CO}_{2}[118,185,186]$ and as a consequence, $\mathrm{CO}_{2}$ availability is a factor that can control the abundance and species composition of submerged macrophytes. Maberly et al. [187] examined the macrophyte composition along a spring river stretch with a strong gradient of $\mathrm{CO}_{2}$ concentrations dropping from 24 to 5 times the atmospheric concentration. At the headwaters, macrophyte composition was dominated by plants that rely on free $\mathrm{CO}_{2}$ such as the moss Fontinalis antipyretica, whereas with lower $\mathrm{CO}_{2}$ concentrations, the macrophyte composition changed to include more plants that are able to use $\mathrm{HCO}_{3}{ }^{-}$. Productive lakes often depletes free $\mathrm{CO}_{2}$ in summer due to uptake by phytoplankton. In 
those lakes, macrophytes depending on free $\mathrm{CO}_{2}$ availability may be restricted to areas with a high organic carbon content in the sediment such as shallow protected bays [185,186].

In general, groundwater-borne DIC is supposed to support macrophyte growth, although few empirical studies are available. Frandsen et al. [188] showed that seeping groundwater increased the DIC supply, enhancing the growth of isoetids and to some extent elodeids inhabiting a groundwater-fed softwater lake. Low $\mathrm{pH}$ in spring water increased the growth of Egeria densa by affecting the free $\mathrm{CO}_{2}$ concentration in the water [189].

In groundwater-fed lakes where $\mathrm{CO}_{2}$ rich water enters the littoral zone, IBF would interrupt the added $\mathrm{CO}_{2}$ contribution and thereby decrease the possibility for $\mathrm{CO}_{2}$-dependent macrophytes to survive. This process has been suggested to be involved in the complete disappearance of F. antipyretica from Lake Müggelsee (Figure 4) during the last century [190]. An overall lower availability of DIC in the littoral zone due to IBF preventing groundwater exfiltration into the lake may eventually lead to an overall loss of macrophytes. This process may be accelerated by shading through planktonic and periphytic algae, which are able to saturate their need for $\mathrm{CO}_{2}$ at low concentrations of free $\mathrm{CO}_{2}$ due to their small size and effective carbon concentrating mechanisms. Consequently, they are able to grow fast, facing less competition for limiting nutrients with macrophytes $[177,191]$.

Usually, lakes with a high abundance of macrophytes are characterized by a higher biodiversity [98], and a loss of macrophytes would thus potentially lead to a decline in biodiversity (Table 2).

\subsection{Dissolved Organic Carbon (DOC)}

Groundwater can contain considerable amounts of dissolved organic carbon (DOC) and be responsible for a significant share of the DOC flux into lakes and rivers ([107] and references therein). Natural DOC in shallow groundwater is mainly derived from decomposing organic matter in the soil and often colours the water yellow/brown [192]. Inputs of terrestrial DOC to surface waters have increased in many north temperate and boreal regions over the past decades [112,193]. This browning has several consequences for recipient aquatic ecosystems. The attenuation of light by coloured DOC restricts the growth of benthic primary producers [111-114]. Williamson et al. [111] also reported fundamental changes in vertical habitat gradients and food web structure in a long-term study on browning in lakes.

Humic substances pose significant challenges during the processing of drinking water supplies ranging from unpleasant taste, odour and colour, to the formation of potentially harmful disinfection by-products when subjected to raw water processing, which often includes treatment with reactive species such as free chlorine, ozone, chloramines, or chlorine dioxide [194]. Since IBF reduces or fully prevents groundwater discharge into inland waters (see e.g., example of Lake Müggelsee), it should thus reduce browning and all changes in water quality affected by it (Table 2). IBF that lowers browning is thus assumed to have a positive effect on biodiversity and macrophyte abundance, while both positive and negative effects on harmful cyanobacteria blooms due to changing light availability and stratification patterns have been reported (Table 2).

\section{Summary on IBF Effects on Surface Water Quality}

In this chapter we summarize the mechanisms by which IBF can affect biodiversity, macrophyte abundance and cyanobacteria blooms and explain the importance of these surface water quality parameters.

\subsection{Biodiversity}

Biodiversity of inland waters has been recognized as an invaluable parameter of the ecological quality of inland waters. In European Union (EU) member states, this recognition has resulted in the implementation of the EU Water Framework Directive in 2000. It represents a radical shift towards measuring the status of all surface waters using a range of biological communities rather than the more 
limited aspects of chemical quality or targeted biological components [195]. In total, 297 assessment methods have been developed by 28 member states with more than half of the methods being based on macroscopic plants (28\%) or benthic invertebrates $(26 \%)$, with the remainder assessing phytoplankton (21\%), fish (15\%) and phytobenthos (10\%) [196]. Jeppesen et al. [197] observed a significant decline in the species richness of zooplankton and submerged macrophytes with increasing total phosphorus (TP) concentrations in the water; while for fish, phytoplankton and floating-leaved macrophytes, species richness was unimodally related to TP, all peaking at $0.1-0.4 \mathrm{mg} \mathrm{P} / \mathrm{L}$.

IBF can potentially affect the diversity of all these components of the biological community via its different influences on physical and chemical parameters (Figure 5). In principle, a negative influence on biodiversity seems possible for fish via discharge reductions (see Section 3.1), for macrophytes via water level fluctuations (see Section 3.2) modification of sediment characteristics (see Section 3.3) and reduced $\mathrm{CO}_{2}$ availability (see Section 3.7) and for fish, plants and phytobenthos via the increased temperature amplitude (see Section 3.4) (Table 2). However, IBF could also have a positive effect by reducing the loading by groundwater-born nutrients, DOC and pollutants, thereby increasing biodiversity of certain organism groups.

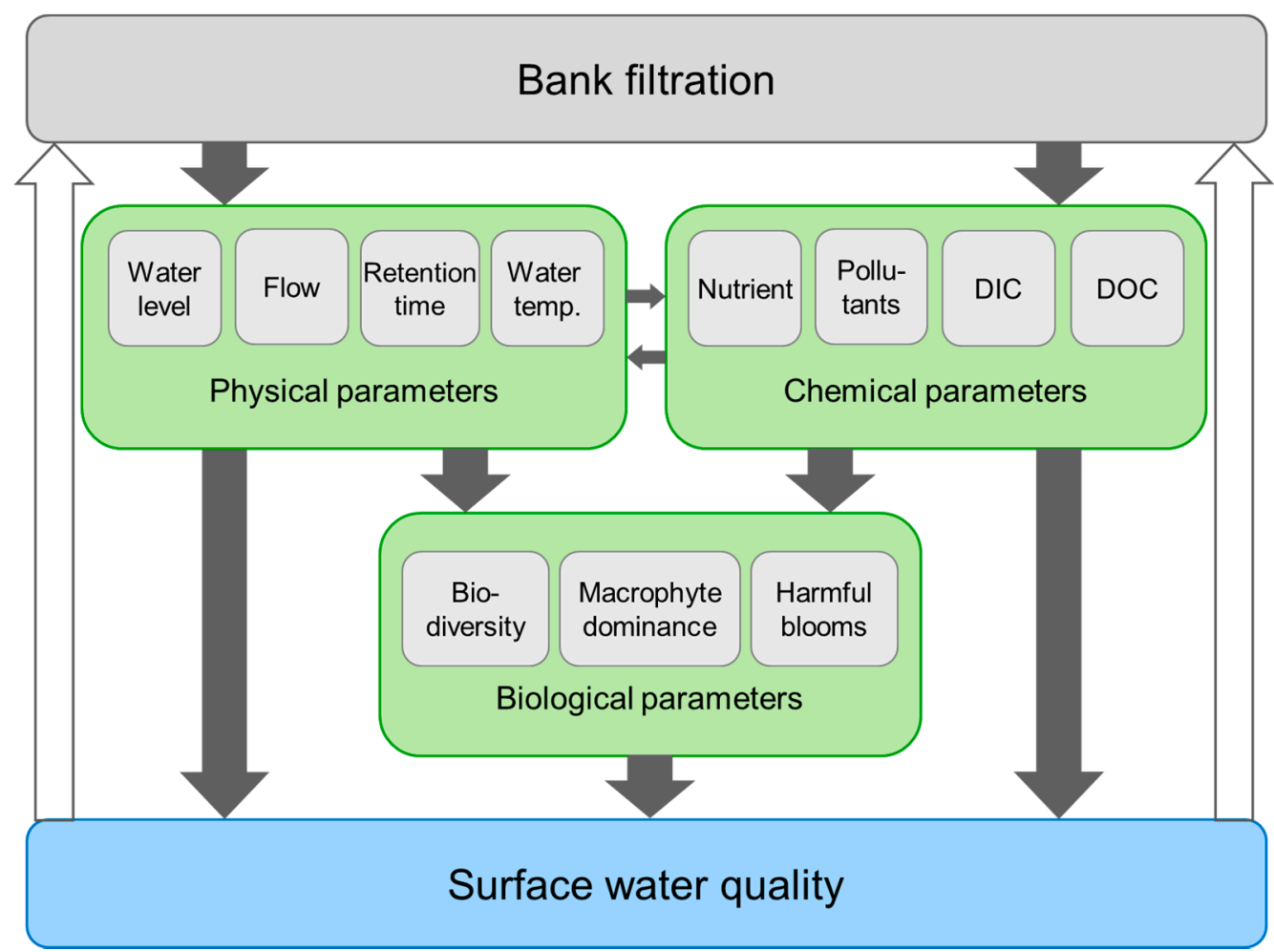

Figure 5. Conceptual scheme of potential links between induced bank filtration and relevant parameters and processes concerning surface water quality (filled arrows, DIC = dissolved inorganic carbon, DOC $=$ dissolved organic carbon). Changes in surface water quality will in turn affect the quality of bank filtrate, which has been the focus of previous research (unfilled arrows).

\subsection{Macrophyte Abundance}

Submerged macrophytes play a key role for controlling water quality, both in lakes and rivers [92,160,162]. Due to a variety of stabilising mechanisms, a positive feedback between water clarity and macrophytes occurs, especially in shallow lakes and lowland rivers [92,160]. These are often either characterised by macrophyte-dominated conditions with clear water or by phytoplankton dominance and a strong risk of harmful cyanobacteria blooms. Abrupt shifts between these states can be triggered either by changes in nutrient loading or by strong perturbations of their biological 
structure such as by macrophyte mowing $[160,198]$. Significantly positive effects of macrophyte stands on water clarity have also been shown for deeper lakes [119,199].

IBF effects on macrophyte abundance may be negative or positive (Figure 5): Macrophyte abundance may be negatively affected by a reduction of $\mathrm{CO}_{2}$ availability (see Section 3.7) and changed redox conditions in the sediments (see Section 3.3) (Table 2). Any negative effects of IBF on macrophytes reduce their inhibiting effects on phytoplankton and thus lower critical threshold levels of shallow lakes for nutrient loading inducing regime shifts to turbid states. They would also reduce their positive effects on mineralization of organic material in the littoral sediments and thus potentially increase the risk of clogging. In contrast, there are also potentially positive effects of IBF on macrophyte abundance, e.g., in water bodies where groundwater discharge is a major source of nutrients, toxic substances inhibiting macrophyte growth, and/or coloured DOC (see Sections 3.5, 3.6 and 3.8) (Table 2).

\subsection{Harmful Cyanobacteria Blooms}

Cyanobacteria blooms are one of the most severe water quality problems in freshwater ecosystems, especially in lakes and reservoirs [108]. Several species of cyanobacteria produce a wide range of toxic compounds [200]. The incidence and intensity of cyanobacteria blooms and the economic losses associated with these events have increased in recent decades $[147,201,202]$. The abatement and control of cyanobacteria that produce toxins and create taste and odour problems in drinking water sources is a major challenge for water supplies (e.g., [5,11]). IBF has been shown potential to effectively remove cyanobacteria during underground passage [203]; however, a recent study indicates the potential for the passage of cells even for filamentous cyanobacterial species ([10] and references therein).

Several factors maintaining cyanobacteria blooms in inland waters are potentially facilitated by IBF such as lower flow, higher retention times (see Section 3.1), lower water levels (see Section 3.2), higher summer water temperatures (see Section 3.4), loss of submerged macrophytes (see Section 4.2) and the prevention of groundwater influx containing humic substances inhibiting cyanobacteria blooms (Figure 5). In contrast, the interruption of nutrient-rich groundwater discharge (see Section 3.5) and DOC to surface water by IBF may combat cyanobacteria blooms (Table 2).

\section{Conclusions}

IBF results in water abstraction from a variety of surface waters worldwide, including ponds, shallow and deep lakes and rivers of different discharge. Being a useful cost-effective and reliable drinking water production method, available studies on IBF only focus on the processes affecting the target drinking water quantity and quality, while its effect on surface waters so far has been ignored.

- We suggest that IBF directly and indirectly affects physical, chemical and biological processes in surface water that may have both negative and positive effects on their water quality (Figure 5). Potential adverse effects would in turn negatively affect the quality of the water abstracted for drinking water production via IBF (Figures 1 and 5). We predict that IBF-induced changes in water temperature, $\mathrm{CO}_{2}$ availability and water retention times in lakes can lead to macrophyte disappearance, phytoplankton dominance and more suitable conditions for cyanobacteria blooms, among other consequences.

- Effects of IBF on surface water bodies are assumed to be highest in cases where discharge or lake volumes are small relative to the amount of water abstracted by IBF.

- Our conceptual impact assessment indicates the need for specific research on IBF effects on source aquatic ecosystems. While field and laboratory experiments may be suitable to test for selected processes, whole ecosystem experiments, monitoring, long-term data sets on aquatic ecosystems before and after the onset of IBF, and modelling are needed to understand the joint impact of IBF.

- Global change and urbanization are expected to increase the number of surface water bodies being used for IBF. Research on how to minimize potential negative impacts of IBF on their source surface water is thus urgently needed to ensure a sustainable use of this valuable technology. 
Author Contributions: M.G. and S.H. conceived the concept, wrote the manuscript and produced figures and tables. G.M. and G.N. participated in the writing and provided feedback on figures and tables. All authors have approved the final article.

Funding: This research was funded by the German Research Foundation grant number GRK 2032/1 (DFG research training group "Urban water interfaces"). The publication of this article was funded by the Open Access Fund of the Leibniz Association.

Acknowledgments: The authors would like to thank the members of the DFG (German Research Foundation) Research Training Group "Urban Water Interfaces", Eckhard Scheffler, the Berlin Senate Department for the Environment, Transport and Climate Protection, especially Antje Köhler, Alexander Limberg, Benjamin Creutzfeldt and Daniel Brüggemann, for providing data and discussions and the Berlin Water Utilities, especially Dörte Siebenthaler, for her invaluable help during data collection. We are thankful for the linguistic improvements made by Kyle Pipkins and Benjamin Kraemer.

Conflicts of Interest: The authors declare no conflicts of interest.

\section{References}

1. Winter, T.C. Ground Water and Surface Water: A Single Resource; U.S. Geological Survey: Denver, CO, USA, 1998; ISBN 978-0-607-89339-7.

2. Ray, C.; Melin, G.; Linsky, R.B. (Eds.) Riverbank Filtration: Improving Source-Water Quality; Water Science and Technology Library; Kluwer Acad. Publ: Dordrecht, The Netherlands, 2002; ISBN 978-1-4020-1133-7.

3. Bouwer, H. Artificial recharge of groundwater: Hydrogeology and engineering. Hydrogeol. J. 2002, 10, 121-142. [CrossRef]

4. Hiscock, K.M.; Grischek, T. Attenuation of groundwater pollution by bank filtration. J. Hydrol. 2002, 266, 139-144. [CrossRef]

5. Chorus, I.; Klein, G.; Fastner, J.; Rotard, W. Off-flavors in surface waters-How efficient is bank filtration for their abatement in drinking-water. Water Sci. Technol. 1992, 25, 251-258. [CrossRef]

6. Jacobson, R.A.; Warner, G.S.; Parasiewicz, P.; Bagtzoglou, A.C.; Ogden, F.L. An interdisciplinary study of the effects of groundwater extraction on freshwater fishes. Int. J. Ecol. Econ. Stat. 2008, 12, 7-25.

7. Schubert, J. Hydraulic aspects of riverbank filtration-Field studies. J. Hydrol. 2002, 266, 145-161. [CrossRef]

8. Umar, D.A.; Ramli, M.F.; Aris, A.Z.; Sulaiman, W.N.A.; Kura, N.U.; Tukur, A.I. An overview assessment of the effectiveness and global popularity of some methods used in measuring riverbank filtration. J. Hydrol. 2017, 550, 497-515. [CrossRef]

9. Lahti, K.; Rapala, J.; Kivimaki, A.L.; Kukkonen, J.; Niemela, M.; Sivonen, K. Occurrence of microcystins in raw water sources and treated drinking water of Finnish waterworks. Water Sci. Technol. 2001, 43, 225-228. [CrossRef] [PubMed]

10. Pazouki, P.; Prévost, M.; McQuaid, N.; Barbeau, B.; de Boutray, M.-L.; Zamyadi, A.; Dorner, S. Breakthrough of cyanobacteria in bank filtration. Water Res. 2016, 102, 170-179. [CrossRef] [PubMed]

11. Zamyadi, A.; MacLeod, S.L.; Fan, Y.; McQuaid, N.; Dorner, S.; Sauve, S.; Prevost, M. Toxic cyanobacterial breakthrough and accumulation in a drinking water plant: A monitoring and treatment challenge. Water Res. 2012, 46, 1511-1523. [CrossRef] [PubMed]

12. Massmann, G.; Nogeitzig, A.; Taute, T.; Pekdeger, A. Seasonal and spatial distribution of redox zones during lake bank filtration in Berlin, Germany. Environ. Geol. 2008, 54, 53-65. [CrossRef]

13. Sprenger, C.; Hartog, N.; Hernández, M.; Vilanova, E.; Grützmacher, G.; Scheibler, F.; Hannappel, S. Inventory of managed aquifer recharge sites in Europe: Historical development, current situation and perspectives. Hydrogeol. J. 2017, 25, 1909-1922. [CrossRef]

14. Tufenkji, N.; Ryan, J.N.; Elimelech, M. The promise of bank filtration. Environ. Sci. Technol. 2002, 36, 422A-428A. [CrossRef] [PubMed]

15. Ray, C.; Schubert, J.; Linsky, R.B.; Melin, G. Introduction. In Riverbank Filtration: Improving Source-Water Quality; Ray, C., Melin, G., Linsky, R.B., Eds.; Water Science and Technology Library; Kluwer Acad. Publ: Dordrecht, The Netherlands, 2002; pp. 1-15. ISBN 978-1-4020-1133-7.

16. Sharma, S.K.; Amy, G.L. Bank filtration: A sustainable water treatment technology for developing countries. In Water, Sanitation and Hygiene: Sustainable Development and Multisectoral Approaches; Water, Engineering and Development Centre, Loughborough University of Technology, WEDC: Addis Ababa, Ethopia, 2009. 
17. Wett, B.; Jarosch, H.; Ingerle, K. Flood induced infiltration affecting a bank filtrate well at the River Enns, Austria. J. Hydrol. 2002, 266, 222-234. [CrossRef]

18. Schön, M. Systematic Comparison of Riverbank Filtration Sites in Austria and India; Leopold Franzens Universität Innsbruck: Innsbruck, Austria, 2014.

19. ICPDR. Groundwater Guidance; International Commission for the Protection of the Danube River: Vienna, Austria, 2016.

20. Miettinen, I.; Martikainen, P.; Vartiainen, T. Humus transformation at the bank filtration water-plant. Water Sci. Technol. 1994, 30, 179-187. [CrossRef]

21. Miettinen, I.T.; Vartiainen, T.; Martikainen, P.J. Bacterial enzyme activities in ground water during bank filtration of lake water. Water Res. 1996, 30, 2495-2501. [CrossRef]

22. Doussan, C.; Ledoux, E.; Detay, M. River-groundwater exchanges, bank filtration, and groundwater quality: Ammonium behavior. J. Environ. Qual. 1998, 27, 1418-1427. [CrossRef]

23. FSO. Public Water Supply; Public Water Supply and Wastewater Treatment; Federal Statistical Office: Wiesbaden, Germany, 2013; p. 18.

24. Schmidt, C.F.; Lange, F.T.; Brauch, H.-J. Assessing the impact of different redox conditions and residence times on the fate of organic micropollutants during riverbank filtration. In Proceedings of the 4th International Conference on Pharmaceuticals and Endocrine Disrupting Chemicals in Water, Minneapolis, MN, USA, 13-15 October 2004; National Ground Water Association: Minneapolis, MN, USA, 2004; pp. 195-205.

25. Hoffmann, A.; Gunkel, G. Carbon input, production and turnover in the interstices of a Lake Tegel bank filtration site, Berlin, Germany. Limnologica 2011, 41, 151-159. [CrossRef]

26. Hoffmann, A.; Gunkel, G. Bank filtration in the sandy littoral zone of Lake Tegel (Berlin): Structure and dynamics of the biological active filter zone and clogging processes. Limnologica 2011, 41, 10-19. [CrossRef]

27. Heberer, T.; Massmann, G.; Fanck, B.; Taute, T.; Duennbier, U. Behaviour and redox sensitivity of antimicrobial residues during bank filtration. Chemosphere 2008, 73, 451-460. [CrossRef] [PubMed]

28. Massmann, G.; Dünnbier, U.; Heberer, T.; Taute, T. Behaviour and redox sensitivity of pharmaceutical residues during bank filtration-Investigation of residues of phenazone-type analgesics. Chemosphere 2008, 71, 1476-1485. [CrossRef] [PubMed]

29. Maeng, S.K.; Ameda, E.; Sharma, S.K.; Grützmacher, G.; Amy, G.L. Organic micropollutant removal from wastewater effluent-impacted drinking water sources during bank filtration and artificial recharge. Water Res. 2010, 44, 4003-4014. [CrossRef] [PubMed]

30. Wiese, B.; Massmann, G.; Jekel, M.; Heberer, T.; Duennbier, U.; Orlikowski, D.; Gruetzmacher, G. Removal kinetics of organic compounds and sum parameters under field conditions for managed aquifer recharge. Water Res. 2011, 45, 4939-4950. [CrossRef] [PubMed]

31. Henzler, A.F.; Greskowiak, J.; Massmann, G. Modeling the fate of organic micropollutants during river bank filtration (Berlin, Germany). J. Contam. Hydrol. 2014, 156, 78-92. [CrossRef] [PubMed]

32. Henzler, A.F.; Greskowiak, J.; Massmann, G. Seasonality of temperatures and redox zonations during bank filtration-A modeling approach. J. Hydrol. 2016, 535, 282-292. [CrossRef]

33. Burke, V.; Greskowiak, J.; Asmuss, T.; Bremermann, R.; Taute, T.; Massmann, G. Temperature dependent redox zonation and attenuation of wastewater-derived organic micropollutants in the hyporheic zone. Sci. Total Environ. 2014, 482, 53-61. [CrossRef] [PubMed]

34. Grützmacher, G.; Böttcher, G.; Chorus, I.; Knappe, A.; Pekdeger, A. Cyanobacterial toxins in bank filtered water from Lake Wannsee, Berlin. In Management of Aquifer Recharge for Sustainability; Dillon, P., Ed.; Swets and Zeitlinger: Lisse, The Netherlands, 2002; pp. 175-179.

35. Heberer, T.; Mechlinski, A.; Fanck, B.; Knappe, A.; Massmann, G.; Pekdeger, A.; Fritz, B. Field Studies on the Fate and Transport of Pharmaceutical Residues in Bank Filtration. Groundw. Monit. Remediat. 2004, 24, 70-77. [CrossRef]

36. Massmann, G.; Sueltenfuss, J.; Duennbier, U.; Knappe, A.; Taute, T.; Pekdeger, A. Investigation of groundwater a residence times during bank filtration in Berlin: Multi-tracer approach. Hydrol. Process. 2008, 22, 788-801. [CrossRef]

37. Kohfahl, C.; Massmann, G.; Pekdeger, A. Sources of oxygen flux in groundwater during induced bank filtration at a site in Berlin, Germany. Hydrogeol. J. 2009, 17, 571-578. [CrossRef]

38. Chorus, I. (Ed.) Cyanotoxins: Occurrence, Causes, Consequences; Springer: Berlin, Germany; New York, NY, USA, 2012; ISBN 978-3-642-59514-1. 
39. Achten, C.; Kolb, A.; Puttmann, W. Occurrence of methyl tert-butyl ether (MTBE) in riverbank filtered water and drinking water produced by riverbank filtration 2. Environ. Sci. Technol. 2002, 36, 3662-3670. [CrossRef] [PubMed]

40. Ray, C.; Soong, T.W.; Lian, Y.Q.; Roadcap, G.S. Effect of flood-induced chemical load on filtrate quality at bank filtration sites. J. Hydrol. 2002, 266, 235-258. [CrossRef]

41. Homonnay, Z. Use of Bank Filtration in Hungary. In Riverbank Filtration: Understanding Contaminant Biogeochemistry and Pathogen Removal; Ray, C., Ed.; Springer: Dordrecht, The Netherlands, 2002; pp. 221-228. ISBN 978-1-4020-0955-6.

42. Rossetto, R.; Barbagli, A.; Borsi, I.; Mazzanti, G.; Vienken, T.; Bonari, E. Site investigation and design of the monitoring system at the Sant'Alessio Induced RiverBank Filtration plant (Lucca, Italy). Rendiconti online della Società Geologica Italiana 2015, 35, 248-251. [CrossRef]

43. Eynard, F.; Mez, K.; Walther, J.-L. Risk of cyanobacterial toxins in Riga waters (Latvia). Water Res. 2000, 34, 2979-2988. [CrossRef]

44. Medema, G.J.; Stuyfzand, P.J. Removal of micro-organisms upon basin recharge, deep well injection and river bank filtration in the Netherlands. In Management of Aquifer Recharge for Sustainability; Dillon, P., Ed.; Swets and Zeitlinger: Lisse, The Netherlands, 2002; pp. 125-131. ISBN 9058095274.

45. Hamann, E.; Stuyfzand, P.J.; Greskowiak, J.; Timmer, H.; Massmann, G. The fate of organic micropollutants during long-term/long-distance river bank filtration. Sci. Total Environ. 2016, 545, 629-640. [CrossRef] [PubMed]

46. Mollema, P.N.; Stuyfzand, P.J.; Juhasz-Holterman, M.H.A.; Van Diepenbeek, P.M.J.A.; Antonellini, M. Metal accumulation in an artificially recharged gravel pit lake used for drinking water supply. J. Geochem. Explor. 2015, 150, 35-51. [CrossRef]

47. Mollema, P.N.; Antonellini, M.; Hubeek, A.; Van Diepenbeek, P.M.J.A. The effect of artificial recharge on hydrochemistry: A comparison of two fluvial gravel pit lakes with different post-excavation uses in the netherlands. Water 2016, 8, 409. [CrossRef]

48. Kvitsand, H.M.L.; Myrmel, M.; Fiksdal, L.; Osterhus, S.W. Evaluation of bank filtration as a pretreatment method for the provision of hygienically safe drinking water in Norway: Results from monitoring at two full-scale sites. Hydrogeol. J. 2017, 25, 1257-1269. [CrossRef]

49. Przybylek, J.; Dragon, K.; Kaczmarek, P.M.J. Hydrogeological investigations of river bed clogging at a river bank filtration site along the River Warta, Poland. Geologos 2017, 23, 201-214. [CrossRef]

50. Rojanschi, V.; Mlenajek, L.; Stanciulesc, M. Riverbank filtration in water supply in Romania-Old solutions, new problems. In Riverbank Filtration: Understanding Contaminant Biogeochemistry and Pathogen Removal; Ray, C., Ed.; Springer Science \& Business Media: Berlin, Germany, 2002; pp. 235-245. ISBN 978-1-4020-0954-9.

51. Vogt, T.; Hoehn, E.; Schneider, P.; Cirpka, O.A. Untersuchung der Flusswasserinfiltration in voralpinen Schottern mittels Zeitreihenanalyse. Grundwasser 2009, 14, 179-194. [CrossRef]

52. Castella, E.; Bickerton, M.; Armitage, P.D.; Petts, G.E. The effects of water abstractions on invertebrate communities in U.K. streams. Hydrobiologia 1995, 308, 167-182. [CrossRef]

53. Ahmed, A.K.A.; Marhaba, T.F. Review on river bank filtration as an in situ water treatment process. Clean Technol. Environ. Policy 2017, 19, 349-359. [CrossRef]

54. Weiss, W.J.; Bouwer, E.J.; Aboytes, R.; LeChevallier, M.W.; O’Melia, C.R.; Le, B.T.; Schwab, K.J. Riverbank filtration for control of microorganisms: Results from field monitoring. Water Res. 2005, 39, 1990-2001. [CrossRef] [PubMed]

55. Sahoo, G.B.; Ray, C.; Wang, J.Z.; Hubbs, S.A.; Song, R.; Jasperse, J.; Seymour, D. Use of artificial neural networks to evaluate the effectiveness of riverbank filtration. Water Res. 2005, 39, 2505-2516. [CrossRef] [PubMed]

56. Ray, C. (Ed.) Riverbank Filtration: Understanding Contaminant Biogeochemistry and Pathogen Removal; Springer Science \& Business Media: Berlin, Germany, 2002; ISBN 978-1-4020-0954-9.

57. Harvey, R.W.; Metge, D.W.; LeBlanc, D.R.; Underwood, J.; Aiken, G.R.; Butler, K.; McCobb, T.D.; Jasperse, J. Importance of the Colmation Layer in the Transport and Removal of Cyanobacteria, Viruses, and Dissolved Organic Carbon during Natural Lake-Bank Filtration. J. Environ. Qual. 2015, 44, 1413-1423. [CrossRef] [PubMed] 
58. Freitas, D.A.; Cabral, J.J.S.P.; Rocha, F.J.S.; Paiva, A.L.R.; Sens, M.L.; Veras, T.B. Cryptosporidium spp. and Giardia spp. removal by bank filtration at Beberibe River, Brazil. River Res. Appl. 2017, 33, 1079-1087. [CrossRef]

59. Romero, L.G.; Mondardo, R.I.; Sens, M.L.; Grischek, T. Removal of cyanobacteria and cyanotoxins during lake bank filtration at Lagoa do Peri, Brazil. Clean Technol. Environ. Policy 2014, 16, 1133-1143. [CrossRef]

60. Romero-Esquivel, L.G.; Pizzolatti, B.S.; Sens, M.L. Potential application of bank filtration in Santa Catarina, Brazil. Interciencia 2016, 41, 740-747.

61. Hu, B.; Teng, Y.; Zhai, Y.; Zuo, R.; Li, J.; Chen, H. Riverbank filtration in China: A review and perspective. J. Hydrol. 2016, 541, 914-927. [CrossRef]

62. Sandhu, C.; Grischek, T.; Kumar, P.; Ray, C. Potential for riverbank filtration in India. Clean Technol. Environ. Policy 2011, 13, 295-316. [CrossRef]

63. Lorenzen, G.; Sprenger, C.; Taute, T.; Pekdeger, A.; Mittal, A.; Massmann, G. Assessment of the potential for bank filtration in a water-stressed megacity (Delhi, India). Environ. Earth Sci. 2010, 61, 1419-1434. [CrossRef]

64. Sharma, B.; Uniyal, D.P.; Dobhal, R.; Kimothi, P.C.; Grischek, T. A sustainable solution for safe drinking water through bank filtration technology in Uttarakhand, India. Curr. Sci. 2014, 107, 1118-1124.

65. Thakur, A.K.; Ojha, C.S.P.; Singh, V.P.; Gurjar, B.R.; Sandhu, C. Removal of pathogens by river bank filtration at Haridwar, India. Hydrol. Process. 2013, 27, 1535-1542. [CrossRef]

66. Dash, R.R.; Mehrotra, I.; Kumar, P.; Grischek, T. Lake bank filtration at Nainital, India: Water-quality evaluation. Hydrogeol. J. 2008, 16, 1089-1099. [CrossRef]

67. Othman, S.Z.; Adlan, M.N.; Selamat, M.R. A study on the potential of riverbank filtration for the removal of color, iron, turbidy and E.coli in Sungai Perak, Kota Lama Kiri, Kuala Kangsar, Perak, Malaysia. Jurnal Teknologi 2015, 74, 83-91. [CrossRef]

68. Bork, J.; Berkhoff, S.E.; Bork, S.; Hahn, H.J. Using subsurface metazoan fauna to indicate groundwater-surface water interactions in the Nakdong River floodplain, South Korea. Hydrogeol. J. 2009, 17, 61-75. [CrossRef]

69. Pholkern, K.; Srisuk, K.; Grischek, T.; Soares, M.; Schäfer, S.; Archwichai, L.; Saraphirom, P.; Pavelic, P.; Wirojanagud, W. Riverbed clogging experiments at potential river bank filtration sites along the Ping River, Chiang Mai, Thailand. Environ. Earth Sci. 2015, 73, 7699-7709. [CrossRef]

70. Ghodeif, K.; Grischek, T.; Bartak, R.; Wahaab, R.; Herlitzius, J. Potential of river bank filtration (RBF) in Egypt. Environ. Earth Sci. 2016, 75, 671. [CrossRef]

71. Shamrukh, M.; Abdel-Wahab, A. Riverbank filtration for sustainable water supply: Application to a large-scale facility on the Nile River. Clean Technol. Environ. Policy 2008, 10, 351-358. [CrossRef]

72. Hamdan, A.M.; Sensoy, M.M.; Mansour, M.S. Evaluating the effectiveness of bank infiltration process in new Aswan City, Egypt. Arab. J. Geosci. 2013, 6, 4155-4165. [CrossRef]

73. Stadtwerke Düsseldorf. Clearly Drinking Water_Element of Life; Stadtwerke Düsseldorf: Düsseldorf, Germany, 2011.

74. Zippel, M.; Hannappel, S. Evaluation of the groundwater yield of Berlin water works using regional numerical groundwater flow models. Grundwasser 2008, 13, 195-207. [CrossRef]

75. Berlin Water Utilities. Groundwater Extraction. Available online: http://www.bwb.de/content/language1/ html/961.php (accessed on 1 June 2018).

76. Berlin Water Utilities. Wasserschutzgebiete auf Einen Blick; Berlin Water Utilities: Berlin, Germany, 2018.

77. Jekel, M.; Ruhl, A.S.; Meinel, F.; Zietzschmann, F.; Lima, S.P.; Baur, N.; Wenzel, M.; Gnirß, R.; Sperlich, A.; Dünnbier, U.; et al. Anthropogenic organic micro-pollutants and pathogens in the urban water cycle: Assessment, barriers and risk communication (ASKURIS). Environ. Sci. Eur. 2013, 25, 20. [CrossRef]

78. Driescher, E.; Behrendt, H.; Schellenberger, G.; Stellmacher, R. Lake Müggelsee and its environment-Natural conditions and anthropogenic impacts. Int. Revue Gesamten Hydrobiol. Hydrogr. 1993, 78, 327-343. [CrossRef]

79. Zippel, M. Model-Based Assessment of the Underground Water Resources of Berlin-The Groundwater Situation in the Catchment Area of Lake Müggelsee; Freie Universität: Berlin, Germany, 2006.

80. Berlin Water Utilities. Pumping Rates from Well Galleries around Lake Müggelsee; Berlin Water Utilities: Berlin, Germany, 2018.

81. Schröter, W. Groundwater Levels of the Main Aquifer and Panke Valley Aquifer. 2015. Available online: http:/ / www.stadtentwicklung.berlin.de/umwelt/umweltatlas/kq212.htm (accessed on 15 May 2018).

82. Frey, W.; Skripalle, J.; Krüger, P. Ecological Consequences of Large-Scale Groundwater Drawdown; Senate of Berlin, Department for the Environment, Transport and Climate Protection: Berlin, Germany, 1992. 
83. Senate of Berlin. Measured and Modelled Water Discharge into Lake Müggelsee; Berlin Senate Department for the Environment, Transport and Climate Protection: Berlin, Germany, 2018.

84. Schumacher, F.; Storz, P. State of Model 2016 and Transient Calculation of the Hydrological Years 2004 to 2014 ; Senate of Berlin, Department for the Environment, Transport and Climate Protection: Berlin, Germany, 2016; 12 .

85. Vollenweider, R.A. Advances in defining critical loading levels for phosphorus in lake eutrophication. Mem. Ist. Ital. Idrobiol. 1976, 33, 53-83.

86. Shatwell, T.; Köhler, J. Decreased nitrogen loading controls summer cyanobacterial blooms without promoting nitrogen-fixing taxa: Long-term response of a shallow lake. Limnol. Oceanogr. 2018. [CrossRef]

87. Bunn, S.E.; Arthington, A.H. Basic principles and ecological consequences of altered flow regimes for aquatic biodiversity. Environ. Manag. 2002, 30, 492-507. [CrossRef]

88. Bickerton, M.; Petts, G.; Armitage, P.; Castella, E. Assessing the ecological effects of groundwater abstraction on chalk streams: Three examples from Eastern England. Regul. Rivers Res. Mgmt. 1993, 8, 121-134. [CrossRef]

89. Acreman, M.C.; Adams, B.; Birchall, P.; Connorton, B. Does groundwater abstraction cause degradation of rivers and wetlands? Water Environ. J. 2000, 14, 200-206. [CrossRef]

90. Hilt, S.; Schoenfelder, I.; Rudnickaa, A.; Carls, R.; Nikolaevich, N.; Sukhodolov, A.; Engelhardt, C. Reconstruction of pristine morphology, flow, nutrient conditions and submerged vegetation of lowland river spree (Germany) from palaeomeanders. River Res. Appl. 2008, 24, 310-329. [CrossRef]

91. Armitage, P.; Petts, G. Biotic score and prediction to assess the effects of water abstractions. Aquat. Conserv. Mar. Freshw. Ecosyst. 1992, 2, 1-17. [CrossRef]

92. Hilt, S.; Koehler, J.; Kozerski, H.-P.; van Nes, E.H.; Scheffer, M. Abrupt regime shifts in space and time along rivers and connected lake systems. Oikos 2011, 120, 766-775. [CrossRef]

93. Liu, C.; Liu, J.; Wang, X.-S.; Zheng, C. Analysis of groundwater-lake interaction by distributed temperature sensing in Badain Jaran Desert, Northwest China. Hydrol. Process. 2016, 30, 1330-1341. [CrossRef]

94. Adrian, R.; Hessen, D.O.; Blenckner, T.; Hillebrand, H.; Hilt, S.; Jeppesen, E.; Livingstone, D.M.; Trolle, D. Environmental impacts-Lake ecosystems. In North Sea Region Climate Change Assessment; Quante, M., Colijn, F., Eds.; Springer International Publ.: Cham, Switzerland, 2016; pp. 315-340. ISBN 978-3-319-39743-6.

95. Mooij, W.M.; Janse, J.H.; Domis, L.N.D.S.; Huelsmann, S.; Ibelings, B.W. Predicting the effect of climate change on temperate shallow lakes with the ecosystem model PCLake. Hydrobiologia 2007, 584, 443-454. [CrossRef]

96. Cieśliński, R.; Piekarz, J.; Zieliński, M. Groundwater supply of lakes: The case of Lake Raduńskie Górne (northern Poland, Kashubian Lake District). Hydrol. Sci. J. 2016, 61, 2427-2434. [CrossRef]

97. Hellsten, S. Environmental Factors and Aquatic Macrophytes in the Littoral Zone of Regulated Lakes; University of Oulo: Oulo, Finland, 2000.

98. Hilt, S.; Brothers, S.; Jeppesen, E.; Veraart, A.J.; Kosten, S. Translating Regime Shifts in Shallow Lakes into Changes in Ecosystem Functions and Services. BioScience 2017, 67, 928-936. [CrossRef]

99. Bakker, E.S.; Hilt, S. Impact of water-level fluctuations on cyanobacterial blooms: Options for management. Aquat. Ecol. 2016, 50, 485-498. [CrossRef]

100. Rorslett, B.; Johansen, S.W. Remedial measures connected with aquatic macrophytes in Norwegian regulated rivers and reservoirs. Regul. Rivers Res. Manag. 1996, 12, 509-522. [CrossRef]

101. Mitrovic, S.M.; Hardwick, L.; Dorani, F. Use of flow management to mitigate cyanobacterial blooms in the Lower Darling River, Australia. J. Plankton Res. 2011, 33, 229-241. [CrossRef]

102. Barko, J.W.; Gunnison, D.; Carpenter, S.R. Sediment interactions with submersed macrophyte growth and community dynamics. Aquat. Bot. 1991, 41, 41-65. [CrossRef]

103. Vandel, E.; Vaasma, T.; Terasmaa, J.; Koff, T.; Vainu, M. Effect of human induced drastic water-level changes to ecologically sensitive small lakes. In Proceedings of 2nd International Conference-Water Resources and Wetlands; Romanian Limnogeographical Association: Târgoviște, Romania, 2014; pp. 204-211.

104. Leyer, I. Predicting plant species' responses to river regulation: The role of water level fluctuations. J. Appl. Ecol. 2005, 42, 239-250. [CrossRef]

105. Rorslett, B. Environmental-factors and aquatic macrophyte response in regulated lakes-A statistical approach. Aquat. Bot. 1984, 19, 199-220. [CrossRef] 
106. Stets, E.G.; Striegl, R.G.; Aiken, G.R.; Rosenberry, D.O.; Winter, T.C. Hydrologic support of carbon dioxide flux revealed by whole-lake carbon budgets. J. Geophys. Res. 2009, 114, G01008. [CrossRef]

107. Périllon, C.; Hilt, S. Groundwater influence differentially affects periphyton and macrophyte production in lakes. Hydrobiologia 2015, 1-13. [CrossRef]

108. O'Neil, J.M.; Davis, T.W.; Burford, M.A.; Gobler, C.J. The rise of harmful cyanobacteria blooms: The potential roles of eutrophication and climate change. Harmful Algae 2012, 14, 313-334. [CrossRef]

109. Jeppesen, E.; Meerhoff, M.; Davidson, T.A.; Trolle, D.; Sondergaard, M.; Lauridsen, T.L.; Beklioglu, M.; Brucet, S.; Volta, P.; Gonzalez-Bergonzoni, I.; et al. Climate change impacts on lakes: An integrated ecological perspective based on a multi-faceted approach, with special focus on shallow lakes. J. Limnol. 2014, 73, 88-111. [CrossRef]

110. Phillips, G.L.; Eminson, D.; Moss, B. A mechanism to account for macrophyte decline in progressively eutrophicated freshwaters. Aquat. Bot. 1978, 4, 103-126. [CrossRef]

111. Williamson, C.E.; Overholt, E.P.; Pilla, R.M.; Leach, T.H.; Brentrup, J.A.; Knoll, L.B.; Mette, E.M.; Moeller, R.E. Ecological consequences of long-term browning in lakes. Sci. Rep. 2016, 5. [CrossRef] [PubMed]

112. Solomon, C.T.; Jones, S.E.; Weidel, B.C.; Buffam, I.; Fork, M.L.; Karlsson, J.; Larsen, S.; Lennon, J.T.; Read, J.S.; Sadro, S.; et al. Ecosystem Consequences of Changing Inputs of Terrestrial Dissolved Organic Matter to Lakes: Current Knowledge and Future Challenges. Ecosystems 2015, 18, 376-389. [CrossRef]

113. Vasconcelos, F.R.; Diehl, S.; Rodriguez, P.; Hedstrom, P.; Karlsson, J.; Bystrom, P. Asymmetrical competition between aquatic primary producers in a warmer and browner world. Ecology 2016, 97, 2580-2592. [CrossRef] [PubMed]

114. Brothers, S.; Koehler, J.; Attermeyer, K.; Grossart, H.P.; Mehner, T.; Meyer, N.; Scharnweber, K.; Hilt, S. A feedback loop links brownification and anoxia in a temperate, shallow lake. Limnol. Oceanogr. 2014, 59, 1388-1398. [CrossRef]

115. Relyea, R.A. The impact of insecticides and herbicides on the biodiversity and productivity of aquatic communities. Ecol. Appl. 2005, 15, 618-627. [CrossRef]

116. Coops, H.; Beklioglu, M.; Crisman, T.L. The role of water-level fluctuations in shallow lake ecosystems-Workshop conclusions. Hydrobiologia 2003, 506-509, 23-27. [CrossRef]

117. Leira, M.; Cantonati, M. Effects of water-level fluctuations on lakes: An annotated bibliography. Hydrobiologia 2008, 613, 171-184. [CrossRef]

118. Scheffer, M. Ecology of Shallow Lakes; Springer: Dordrecht, The Netherlands, 2004; ISBN 978-1-4020-2306-4.

119. Sachse, R.; Petzoldt, T.; Blumstock, M.; Moreira, S.; Paetzig, M.; Ruecker, J.; Janse, J.H.; Mooij, W.M.; Hilt, S. Extending one-dimensional models for deep lakes to simulate the impact of submerged macrophytes on water quality. Environ. Model. Softw. 2014, 61, 410-423. [CrossRef]

120. Wiese, B.; Nützmann, G. Transient leakance and infiltration characteristics during lake bank filtration. Groundwater 2009, 47, 57-68. [CrossRef] [PubMed]

121. WASY. Hydrogeological Report on the Impact of Fundamental Changes in the Operation of Groundwater Enrichment at Tegel Waterworks; WASY Institute for Water Resources Planning and Systems Research Ltd.: Berlin, Germany, 2004.

122. Gunkel, G.; Beulker, C.; Hoffmann, A.; Kosmol, J. Fine particulate organic matter (FPOM) transport and processing in littoral interstices-Use of fluorescent markers. Limnologica 2009, 39, 185-199. [CrossRef]

123. Van Zuidam, B.G.; Cazemier, M.M.; van Geest, G.J.; Roijackers, R.M.M.; Peeters, E.T.H.M. Relationship between redox potential and the emergence of three submerged macrophytes. Aquat. Bot. 2014, 113, 56-62. [CrossRef]

124. Ding, S.; Wang, Y.; Wang, D.; Li, Y.Y.; Gong, M.; Zhang, C. In situ, high-resolution evidence for iron-coupled mobilization of phosphorus in sediments. Sci. Rep. 2016, 6, 24341. [CrossRef] [PubMed]

125. Shaheen, S.M.; Rinklebe, J.; Rupp, H.; Meissner, R. Temporal dynamics of pore water concentrations of Cd, $\mathrm{Co}, \mathrm{Cu}, \mathrm{Ni}$, and $\mathrm{Zn}$ and their controlling factors in a contaminated floodplain soil assessed by undisturbed groundwater lysimeters. Environ. Pollut. 2014, 191, 223-231. [CrossRef] [PubMed]

126. Uhlmann, W.; Zimmermann, K. Case Analysis of the Sulphate Load in the River Spree 2014/15; Senate of Berlin, Department for the Environment, Transport and Climate Protection: Dresden, Germany, 2015; 96p.

127. Koch, M.S.; Mendelssohn, I.A.; McKee, K.L. Mechanism for the hydrogen sulfide-induced growth limitation in wetland macrophytes. Limnol. Oceanogr. 1990, 35, 399-408. [CrossRef] 
128. Bayarsaikhan, U.; Filter, J.; Gernert, U.; Jekel, M.; Ruhl, A.S. Fate of leaf litter deposits and impacts on oxygen availability in bank filtration column studies. Environ. Res. 2018, 164, 495-500. [CrossRef] [PubMed]

129. Hannah, D.M.; Webb, B.W.; Nobilis, F. River and stream temperature: Dynamics, processes, models and implications-Preface. Hydrol. Process. 2008, 22, 899-901. [CrossRef]

130. Boisneau, C.; Moatar, F.; Bodin, M.; Boisneau, P. Does global warming impact on migration patterns and recruitment of Allis shad (Alosa alosa L.) young of the year in the Loire River, France? Hydrobiologia 2008, 602, 179-186. [CrossRef]

131. Yvon-Durocher, G.; Montoya, J.M.; Trimmer, M.; Woodward, G. Warming alters the size spectrum and shifts the distribution of biomass in freshwater ecosystems. Glob. Chang. Biol. 2011, 17, 1681-1694. [CrossRef]

132. Hussner, A.; van Dam, H.; Vermaat, J.E.; Hitt, S. Comparison of native and neophytic aquatic macrophyte developments in a geothermally warmed river and thermally normal channels. Fundam. Appl. Limnol. 2014, 185, 155-165. [CrossRef]

133. Boscarino, B.T.; Rudstam, L.G.; Mata, S.; Gal, G.; Johannsson, O.E.; Mills, E.L. The effects of temperature and predator-Prey interactions on the migration behavior and vertical distribution of Mysis relicta. Limnol. Oceanogr. 2007, 52, 1599-1613. [CrossRef]

134. Wehrly, K.E.; Wang, L.; Mitro, M. Field-based estimates of thermal tolerance limits for trout: Incorporating exposure time and temperature fluctuation. Trans. Am. Fish. Soc. 2007, 136, 365-374. [CrossRef]

135. Power, G.; Brown, R.S.; Imhof, J.G. Groundwater and fish-Insights from northern North America. Hydrol. Process. 1999, 13, 401-422. [CrossRef]

136. Imholt, C.; Gibbins, C.N.; Malcolm, I.A.; Langan, S.; Soulsby, C. Influence of riparian cover on stream temperatures and the growth of the mayfly Baetis rhodani in an upland stream. Aquat. Ecol. 2010, 44, 669-678. [CrossRef]

137. Jensen, A.J. Atlantic salmon (Salmo salar) in the regulated River Alta: Effects of altered water temperature on parr growth. River Res. Appl. 2003, 19, 733-747. [CrossRef]

138. Whitledge, G.W.; Rabeni, C.F.; Annis, G.; Sowa, S.P. Riparian Shading and Groundwater Enhance Growth Potential for Smallmouth Bass in Ozark Streams. Ecol. Appl. 2006, 16, 1461-1473. [CrossRef]

139. Gerten, D.; Adrian, R. Species-specific changes in the phenology and peak abundance of freshwater copepods in response to warm summers. Freshw. Biol. 2002, 47, 2163-2173. [CrossRef]

140. Harper, M.P.; Peckarsky, B.L. Emergence cues of a mayfly in a high-altitude stream ecosystem: Potential response to climate change. Ecol. Appl. 2006, 16, 612-621. [CrossRef]

141. Alvarez, D.; Nicieza, A.G. Compensatory response "defends" energy levels but not growth trajectories in brown trout, Salmo trutta L. Proc. R. Soc. B Biol. Sci. 2005, 272, 601-607. [CrossRef] [PubMed]

142. Yvon-Durocher, G.; Jones, J.I.; Trimmer, M.; Woodward, G.; Montoya, J.M. Warming alters the metabolic balance of ecosystems. Philos. Trans. R. Soc. B Biol. Sci. 2010, 365, 2117-2126. [CrossRef] [PubMed]

143. McKee, D.; Atkinson, D.; Collings, S.; Eaton, J.; Harvey, I.; Heyes, T.; Hatton, K.; Wilson, D.; Moss, B. Macro-zooplankter responses to simulated climate warming in experimental freshwater microcosms. Freshw. Biol. 2002, 47, 1557-1570. [CrossRef]

144. Mahdy, A.; Hilt, S.; Filiz, N.; Beklioğlu, M.; Hejzlar, J.; Özkundakci, D.; Papastergiadou, E.; Scharfenberger, U.; Šorf, M.; Stefanidis, K.; et al. Effects of water temperature on summer periphyton biomass in shallow lakes: A pan-European mesocosm experiment. Aquat. Sci. 2015, 77, 499-510. [CrossRef]

145. Velthuis, M.; Domis, L.N.; Frenken, T.; Stephan, S.; Kazanjian, G.; Aben, R.; Hilt, S.; Kosten, S.; van Donk, E.; Van de Waal, D.B. Warming advances top-down control and reduces producer biomass in a freshwater plankton community. Ecosphere 2017, 8, e01651. [CrossRef]

146. Kazanjian, G.; Velthuis, M.; Aben, R.; Stephan, S.; Peeters, E.T.H.M.; Frenken, T.; Touwen, J.; Xue, F.; Kosten, S.; Van de Waal, D.B.; et al. Impacts of warming on top-down and bottom-up controls of periphyton production. Sci. Rep. 2018, 8. [CrossRef] [PubMed]

147. Paerl, H.W.; Huisman, J. Climate change: A catalyst for global expansion of harmful cyanobacterial blooms. Environ. Microbiol. Rep. 2009, 1, 27-37. [CrossRef] [PubMed]

148. Huber, V.; Wagner, C.; Gerten, D.; Adrian, R. To bloom or not to bloom: Contrasting responses of cyanobacteria to recent heat waves explained by critical thresholds of abiotic drivers. Oecologia 2012, 169, 245-256. [CrossRef] [PubMed] 
149. Kosten, S.; Huszar, V.L.M.; Bécares, E.; Costa, L.S.; van Donk, E.; Hansson, L.-A.; Jeppesen, E.; Kruk, C.; Lacerot, G.; Mazzeo, N.; et al. Warmer climates boost cyanobacterial dominance in shallow lakes. Glob. Chang. Biol. 2012, 18, 118-126. [CrossRef]

150. Jensen, H.S.; Andersen, F.O. Importance of temperature, nitrate, and $\mathrm{pH}$ for phosphate release from aerobic sediments of four shallow, eutrophic lakes. Limnol. Oceanogr. 1992, 37, 577-589. [CrossRef]

151. Bannick, C.; Engelmann, B.; Fendler, J.; Frauenstein, J.; Ginzky, H.; Hornemann, C.; Ilvonen, O.; Kirschbaum, B.; Penn-Bressel, G.; Rechenberg, J.; et al. Groundwater in Germany; Federal Ministry for the Environment, Nature Conservation, Building and Nuclear Safety: Bonn, Germany, 2008; p. 72.

152. Schuetz, T.; Weiler, M. Quantification of localized groundwater inflow into streams using ground-based infrared thermography. Geophys. Res. Lett. 2011, 38, L03401. [CrossRef]

153. Sebok, E.; Duque, C.; Kazmierczak, J.; Engesgaard, P.; Nilsson, B.; Karan, S.; Frandsen, M. High-resolution distributed temperature sensing to detect seasonal groundwater discharge into Lake Vaeng, Denmark. Water Resour. Res. 2013, 49, 5355-5368. [CrossRef]

154. Whitehead, P.G.; Wilby, R.L.; Battarbee, R.W.; Kernan, M.; Wade, A.J. A review of the potential impacts of climate change on surface water quality. Hydrol. Sci. J. 2009, 54, 101-123. [CrossRef]

155. Vanek, V. Riparian Zone as a Source of Phosphorus for a Groundwater-Dominated Lake. Water Res. 1991, 25, 409-418. [CrossRef]

156. Meinikmann, K.; Hupfer, M.; Lewandowski, J. Phosphorus in groundwater discharge-A potential source for lake eutrophication. J. Hydrol. 2015, 524, 214-226. [CrossRef]

157. Ouyang, Y. Estimation of shallow groundwater discharge and nutrient load into a river. Ecol. Eng. 2012, 38, 101-104. [CrossRef]

158. Perillon, C.; Poeschke, F.; Lewandowski, J.; Hupfer, M.; Hilt, S. Stimulation of epiphyton growth by lacustrine groundwater discharge to an oligo-mesotrophic hard-water lake. Freshw. Sci. 2017, 36, 555-570. [CrossRef]

159. Phillips, G.; Willby, N.; Moss, B. Submerged macrophyte decline in shallow lakes: What have we learnt in the last forty years? Aquat. Bot. 2016, 135, 37-45. [CrossRef]

160. Scheffer, M.; Hosper, S.; Meijer, M.; Moss, B.; Jeppesen, E. Alternative Equilibria in Shallow Lakes. Trends Ecol. Evol. 1993, 8, 275-279. [CrossRef]

161. Hilt, S.; Koehler, J.; Adrian, R.; Monaghan, M.T.; Sayer, C.D. Clear, crashing, turbid and back-Long-term changes in macrophyte assemblages in a shallow lake. Freshw. Biol. 2013, 58, 2027-2036. [CrossRef]

162. Hilt, S. Regime shifts between macrophytes and phytoplankton-Concepts beyond shallow lakes, unravelling stabilizing mechanisms and practical consequences. Limnetica 2015, 34, 467-479.

163. Bradley, P.M.; Barber, L.B.; Duris, J.W.; Foreman, W.T.; Furlong, E.T.; Hubbard, L.E.; Hutchinson, K.J.; Keefe, S.H.; Kolpin, D.W. Riverbank filtration potential of pharmaceuticals in a wastewater-impacted stream. Environ. Pollut. 2014, 193, 173-180. [CrossRef] [PubMed]

164. Haack, S.K.; Metge, D.W.; Fogarty, L.R.; Meyer, M.T.; Barber, L.B.; Harvey, R.W.; LeBlanc, D.R.; Kolpin, D.W. Effects on groundwater microbial communities of an engineered 30-Day in situ exposure to the antibiotic sulfamethoxazole. Environ. Sci. Technol. 2012, 46, 7478-7486. [CrossRef] [PubMed]

165. Zhao, J.-L.; Zhang, Q.-Q.; Chen, F.; Wang, L.; Ying, G.-G.; Liu, Y.-S.; Yang, B.; Zhou, L.-J.; Liu, S.; Su, H.-C.; et al. Evaluation of triclosan and triclocarban at river basin scale using monitoring and modeling tools: Implications for controlling of urban domestic sewage discharge. Water Res. 2013, 47, 395-405. [CrossRef] [PubMed]

166. Eerkes-Medrano, D.; Thompson, R.C.; Aldridge, D.C. Microplastics in freshwater systems: A review of the emerging threats, identification of knowledge gaps and prioritisation of research needs. Water Res. 2015, 75, 63-82. [CrossRef] [PubMed]

167. Conkle, J.L.; Gan, J.; Anderson, M.A. Degradation and sorption of commonly detected PPCPs in wetland sediments under aerobic and anaerobic conditions. J. Soils Sediments 2012, 12, 1164-1173. [CrossRef]

168. Ebele, A.J.; Abou-Elwafa Abdallah, M.; Harrad, S. Pharmaceuticals and personal care products (PPCPs) in the freshwater aquatic environment. Emerg. Contam. 2017, 3, 1-16. [CrossRef]

169. Drury, B.; Rosi-Marshall, E.; Kelly, J.J. Wastewater treatment effluent reduces the abundance and diversity of benthic bacterial communities in urban and suburban rivers. Appl. Environ. Microbiol. 2013, 79, 1897-1905. [CrossRef] [PubMed]

170. Roy, J.W.; Malenica, A. Nutrients and toxic contaminants in shallow groundwater along Lake Simcoe urban shorelines. Inland Waters 2013, 3, 125-138. [CrossRef] 
171. Sand-Jensen, K. Environmental variables and their effect on photosynthesis of aquatic plant communities. Aquat. Bot. 1989, 34, 5-25. [CrossRef]

172. Maberly, S.C.; Madsen, T.V. Affinity for $\mathrm{CO}_{2}$ in relation to the ability of freshwater macrophytes to use $\mathrm{HCO}^{-}{ }_{3}$. Funct. Ecol. 1998, 12, 99-106. [CrossRef]

173. Demars, B.O.L.; Tremolieres, M. Aquatic macrophytes as bioindicators of carbon dioxide in groundwater fed rivers. Sci. Total Environ. 2009, 407, 4752-4763. [CrossRef] [PubMed]

174. Cole, J.J.; Caraco, N.F.; Kling, G.W.; Kratz, T.K. Carbon Dioxide Supersaturation in the Surface Waters of Lakes. Science 1994, 265, 1568-1570. [CrossRef] [PubMed]

175. Weyhenmeyer, G.A.; Kosten, S.; Wallin, M.B.; Tranvik, L.J.; Jeppesen, E.; Roland, F. Significant fraction of $\mathrm{CO}_{2}$ emissions from boreal lakes derived from hydrologic inorganic carbon inputs. Nat. Geosci. 2015, 8, 933-936. [CrossRef]

176. Marce, R.; Obrador, B.; Morgui, J.-A.; Lluis Riera, J.; Lopez, P.; Armengol, J. Carbonate weathering as a driver of $\mathrm{CO}_{2}$ supersaturation in lakes. Nat. Geosci. 2015, 8, 107-111. [CrossRef]

177. Sand-Jensen, K.; Borum, J. Interactions among phytoplankton, periphyton, and macrophytes in temperate freshwaters and estuaries. Aquat. Bot. 1991, 41, 137-175. [CrossRef]

178. Sand-Jensen, K.; Staehr, P.A. $\mathrm{CO}_{2}$ dynamics along Danish lowland streams: Water-air gradients, piston velocities and evasion rates. Biogeochemistry 2012, 111, 615-628. [CrossRef]

179. Macpherson, G.L. $\mathrm{CO}_{2}$ distribution in groundwater and the impact of groundwater extraction on the global C cycle. Chem. Geol. 2009, 264, 328-336. [CrossRef]

180. Vesper, D.J.; Edenborn, H.M. Determination of free $\mathrm{CO}_{2}$ in emergent groundwaters using a commercial beverage carbonation meter. J. Hydrol. 2012, 438-439, 148-155. [CrossRef]

181. Hutchinson, G.E. A Treatise on Limnology. 3: Limnological Botany; Wiley: New York, NY, USA, 1975; ISBN 978-0-471-42574-8.

182. Moss, B. Ecology of Fresh Waters: Man and Medium, 2nd ed.; Blackwell Science: Oxford, UK, 1996; ISBN 978-0-632-01642-6.

183. Jones, J.I. The metabolic cost of bicarbonate use in the submerged plant Elodea nuttallii. Aquat. Bot. 2005, 83, 71-81. [CrossRef]

184. Olesen, B.; Madsen, T.V. Growth and physiological acclimation to temperature and inorganic carbon availability by two submerged aquatic macrophyte species, Callitriche cophocarpa and Elodea canadensis. Funct. Ecol. 2000, 14, 252-260. [CrossRef]

185. Maberly, S.C. Photosynthesis by Fontinalis antipyretica. I. New Phytol. 1985, 100, 127-140. [CrossRef]

186. Maberly, S.C. Photosynthesis by Fontinalis antipyretica. II. New Phytol. 1985, 100, 141-155. [CrossRef]

187. Maberly, S.C.; Berthelot, S.A.; Stott, A.W.; Gontero, B. Adaptation by macrophytes to inorganic carbon down a river with naturally variable concentrations of $\mathrm{CO}_{2}$. J. Plant Physiol. 2015, 172, 120-127. [CrossRef] [PubMed]

188. Frandsen, M.; Nilsson, B.; Engesgaard, P.; Pedersen, O. Groundwater seepage stimulates the growth of aquatic macrophytes. Freshw. Biol. 2012, 57, 907-921. [CrossRef]

189. Takahashi, K.; Asaeda, T. The effect of spring water on the growth of a submerged macrophyte Egeria densa. Landsc. Ecol. Eng. 2012, 10, 99-107. [CrossRef]

190. Korner, S. Development of submerged macrophytes in shallow Lake Muggelsee (Berlin, Germany) before and after its switch to the phytoplankton-dominated state. Arch. Hydrobiol. 2001, 152, 395-409. [CrossRef]

191. Maberly, S.C. The fitness of the environments of air and water for photosynthesis, growth, reproduction and dispersal of photoautotrophs: An evolutionary and biogeochemical perspective. Aquat. Bot. 2014, 118, 4-13. [CrossRef]

192. Gooddy, D.C.; Shand, P.; Kinniburgh, D.G.; Van Riemsdijk, W.H. Field-based partition coefficients for trace elements in soil solutions. Eur. J. Soil Sci. 1995, 46, 265-285. [CrossRef]

193. Monteith, D.T.; Stoddard, J.L.; Evans, C.D.; de Wit, H.A.; Forsius, M.; Hogasen, T.; Wilander, A.; Skjelkvale, B.L.; Jeffries, D.S.; Vuorenmaa, J.; et al. Dissolved organic carbon trends resulting from changes in atmospheric deposition chemistry. Nature 2007, 450, 537-540. [CrossRef] [PubMed]

194. Reckhow, D.; Singer, P.; Malcolm, R. Chlorination of humic materials: Byproduct formation and chemical interpretations. Environ. Sci. Technol. 1990, 24, 1655-1664. [CrossRef] 
195. Reyjol, Y.; Argillier, C.; Bonne, W.; Borja, A.; Buijse, A.D.; Cardoso, A.C.; Daufresne, M.; Kernan, M.; Ferreira, M.T.; Poikane, S.; et al. Assessing the ecological status in the context of the European Water Framework Directive: Where do we go now? Sci. Total Environ. 2014, 497, 332-344. [CrossRef] [PubMed]

196. Birk, S.; Bonne, W.; Borja, A.; Brucet, S.; Courrat, A.; Poikane, S.; Solimini, A.; van de Bund, W.; Zampoukas, N.; Hering, D. Three hundred ways to assess Europe's surface waters: An almost complete overview of biological methods to implement the Water Framework Directive. Ecol. Indic. 2012, 18, 31-41. [CrossRef]

197. Jeppesen, E.; Jensen, J.P.; Sondergaard, M.; Lauridsen, T.; Landkildehus, F. Trophic structure, species richness and biodiversity in Danish lakes: Changes along a phosphorus gradient. Freshw. Biol. 2000, 45, 201-218. [CrossRef]

198. Kuiper, J.J.; Verhofstad, M.J.J.M.; Louwers, E.L.M.; Bakker, E.S.; Brederveld, R.J.; van Gerven, L.P.A.; Janssen, A.B.G.; de Klein, J.J.M.; Mooij, W.M. Mowing submerged macrophytes in shallow lakes with alternative stable states: Battling the good guys? Environ. Manag. 2017, 59, 619-634. [CrossRef] [PubMed]

199. Hilt, S.; Henschke, I.; Ruecker, J.; Nixdorf, B. Can submerged macrophytes influence turbidity and trophic state in deep lakes? Suggestions from a case study. J. Environ. Qual. 2010, 39, 725-733. [CrossRef] [PubMed]

200. Rastogi, R.P.; Sinha, R.P.; Incharoensakdi, A. The cyanotoxin-microcystins: Current overview. Rev. Environ. Sci. Biol. Technol. 2014, 13, 215-249. [CrossRef]

201. Chorus, I.; Bartram, J. (Eds.) Toxic Cyanobacteria in Water: A Guide to Their Public Health Consequences, Monitoring, and Management; E \& FN Spon: London, UK; New York, NY, USA, 1999; ISBN 978-0-419-23930-7.

202. Heisler, J.; Glibert, P.M.; Burkholder, J.M.; Anderson, D.M.; Cochlan, W.; Dennison, W.C.; Dortch, Q.; Gobler, C.J.; Heil, C.A.; Humphries, E.; et al. Eutrophication and harmful algal blooms: A scientific consensus. Harmful Algae 2008, 8, 3-13. [CrossRef] [PubMed]

203. Grützmacher, G.; Wiese, B.; Hülsoff, I.; Orlikowski, D.; Hoa, E.; Moreau-Le Golvan, Y. Bank Filtration and Aquifer Recharge for Drinking Water Production: Application, Efficiency and Perspectives-An Integration of NASRI Outcomes and International Experiences; Kompetenzzentrum Wasser Berlin gGmbH: Berlin, Germany, 2011.

(C) 2018 by the authors. Licensee MDPI, Basel, Switzerland. This article is an open access article distributed under the terms and conditions of the Creative Commons Attribution (CC BY) license (http:// creativecommons.org/licenses/by/4.0/). 